\title{
The Late Quaternary tephrostratigraphy of annually laminated sediments from Meerfelder Maar, Germany
}

\author{
Christine S. Lane ${ }^{1,2,{ }^{*}}$, Achim Brauer ${ }^{3}$, Celia Martín-Puertas ${ }^{3}$, Simon P.E. Blockley ${ }^{4}$, Victoria C. \\ Smith $^{2}$ and Emma L. Tomlinson ${ }^{5,6}$. \\ 1. Department of Geography, University of Manchester, Arthur Lewis Building, Oxford Road, Manchester, M13 \\ 9PL, United Kingdom. \\ 2. Research Laboratory for Archaeology and the History of Art, University of Oxford, Dyson Perrins Building, \\ South Parks Road, Oxford, OX1 3QY, United Kingdom. \\ 3. GFZ German Research Centre for Geosciences, Section 5.2 Climate Dynamics and Landscape Evolution, \\ Potsdam, Germany. \\ ${ }^{4 .}$ Centre for Quaternary Research, Royal Holloway University of London, Egham, Surrey, TW20 OEX, United \\ Kingdom. \\ 5. Department of Geology, Trinity College Dublin, College Green, Dublin 2, Republic of Ireland. \\ 6. Department of Earth Sciences, Royal Holloway University of London, United Kingdom. \\ *corresponding author: christine.lane@manchester.ac.uk
}

\section{Abstract}

The record of Late Quaternary environmental change within the sediments of Meerfelder Maar in the Eifel region of Germany is renowned for its high precision chronology, which is annually laminated throughout the Last Glacial to Interglacial transition (LGIT) and most of the Holocene. Two visible tephra layers are prominent within the floating varve chronology of Meerfelder Maar. An Early Holocene tephra layer, the Ulmener Maar Tephra $(\sim 11,000$ varve years BP), provides a tie-line of the Meerfelder Maar record to the varved Holocene record of nearby Lake Holzmaar. The Laacher See Tephra provides another prominent time marker for the late Allerød, 200 varve years before the transition into the Younger Dryas at 12,680 varve years BP. Further investigation has now shown that there are also 15 cryptotephra layers within the Meerfelder Maar LGIT-Holocene stratigraphy and these layers hold the potential to make direct comparisons between the Meerfelder Maar record and other palaeoenvironmental archives from across Europe and the North Atlantic. Most notable is the presence of the Vedde Ash, the most widespread Icelandic eruption known from the Late Quaternary, which occurred midway through the Younger Dryas. The Vedde Ash has also been found in the Greenland ice cores and can be used as an isochron around which the GICCO5 and Meerfelder Maar annual chronologies can be compared. Near the base of the annual laminations in Meerfelder Maar a cryptotephra is found that correlates to the Neapolitan Yellow Tuff, erupted from Campi Flegrei in southern Italy, $1200 \mathrm{~km}$ away. This is the furthest north that the Neapolitan Yellow Tuff has been found, highlighting its importance in the construction of a European-wide tephrostratigraphic framework. The colocation of cryptotephra layers from Italian, Icelandic and Eifel volcanic sources, within such a precise chronological record, makes Meerfelder Maar one of the most important tephrostratotype records for continental Europe during the Last Glacial to Interglacial transition.

Keywords: tephrostratigraphy, cryptotephra, Lateglacial, varves, Meerfelder Maar.

\section{Introduction}

The detection of microscopic layers of volcanic ash (cryptotephra) within terrestrial, marine and ice core records is revolutionising the way widespread palaeoenvironmental archives are dated and compared. Tephra isochrons provide stratigraphic tie-lines between records, which permit precise inter-site correlation and comparison of the proxy record, whilst 
avoiding un-grounded assumptions of synchronicity. In addition, where tephra can be correlated to eruptions of known age, absolute age estimates can be achieved and transferred between records. Consequently, the last two decades have seen rapid growth in cryptotephra research, most notably within Late Quaternary palaeoenvironmental studies (e.g., Dugmore et al., 1995; Lowe, 2001; Wulf et al., 2004), but also within archaeological investigations (e.g., Plunkett, 2009; Housley et al., 2012; Lane et al., 2014). Across Europe in particular, there is now a wealth of tephrostratigraphic and chronological data that can be built into a regional tephrostratigraphic framework of interconnected sites, within which questions about the timing of environmental and climatic changes can be addressed (Blockley et al., 2012; Davies et al., 2012; Lane et al., 2012a; Wulf et al., 2013).

Key to the development of a regional tephrostratigraphic framework are two different sorts of distal sites: (i) linking sites that contain tephra records of multiple eruptions from different volcanic sources (e.g., Lane et al., 2011a) and (ii) chronological reference sites with annual to decadal precision, that can feedback dating information to sites around the network (e.g. the Greenland ice core records, Mortensen et al., 2005; Abbott and Davies, 2012). The rare sites that are able to fulfil both of these criteria are typically (partially, or wholly) varved records that sit within the fallout ranges of multiple volcanic centres. European examples include the Lateglacial to Early Holocene record in Soppensee, Switzerland (Hajdas, 1993; Lane et al., 2011b) and the 133 ka record in Lago Grande di Monticchio, Italy (Wulf et al., 2004; Wulf et al., 2008; Wulf et al., 2012).

A major strength of varve sequences lies in the opportunity to date the intervals between tephra isochrons, with annual to decadal precision. This differential dating approach provides important chronological constraints that can be built into a regional tephrostratigraphic framework and used to precisely compare periods of known equivalent duration wherever the same tephra layers are found co-registered. The combination of widespread tephra layers in varve palaeoenvironmental sequences therefore provides the rare, but exceptionally valuable, opportunity to study subtle variations in the timing and rate of environmental response to past abrupt climate changes (Lane et al., 2013).

A cryptotephra study of the Lateglacial to Holocene age sediments from Meerfelder Maar, in the Eifel region of Germany, was carried out with the aim of establishing a new European tephrostratotype sequence in a site that has high (seasonal to annual) chronological resolution as well as the potential to contain tephra from a number of European volcanic centres (the Eifel, Massif Central, Icelandic and Italian). This paper presents the full results of this study, with the following three objectives:

i. To report the Lateglacial and Holocene tephrostratigraphy of Meerfelder Maar. ii. To provide improved varve-age estimates, with uncertainties, for a number of the tephra layers within Meerfelder Maar and to constrain the inter-eruption ages. iii. To place the Meerfelder Maar record within a broader European tephrostratigraphic framework, which permits direct correlation of palaeoenvironmental archives from the North Atlantic, Europe and the Mediterranean.

\section{Site \& methods}

\subsection{The site}

Lake Meerfelder Maar ( $50^{\circ} 06^{\prime} \mathrm{N}, 6^{\circ} 45^{\prime} \mathrm{E}, 336.5 \mathrm{~m}$ a.s.l.) is located in the Eifel region, Germany (Fig. 1), within a volcanic crater formed a minimum of $30 \mathrm{ka}$ BP according to previous radiocarbon dating (Büchel and Lorenz, 1984; Brauer et al., 1999) or even ca $80 \pm 8$ 
ka BP according to recent thermoluminescence dating (Zöller and Blanchard, 2009). The lake has a surface area of approximately $248 \mathrm{~m}^{2}$ and a maximum depth of $18 \mathrm{~m}$. The lake catchment is small, defined by the steep, vegetated, crater walls, which reach up to $520 \mathrm{~m}$ at their highest.

The Holocene varved sediments are composed of spring/summer diatomaceous organic sub-layers and winter sub-layers of allochthonous sediment (Brauer et al., 1999), whereas the lateglacial sediments exhibit a succession of different varves types including siderite varves (late Allerød) and clastic-dominated snow melt varves (second half of Younger Dryas), triggered by rapid climate changes and lake evolution (Brauer et al.,1999). The sediment formation in Lake Meerfelder Maar is sensitive to North Atlantic climate variability. Abrupt sedimentary and biological responses to Lateglacial and Holocene climatic shifts recorded at Meerfelder have provided new insights into the nature and mechanism of Late Quaternary climate dynamics (Brauer et al., 2008; Martin-Puertas et al., 2012a; MartinPuertas et al., 2012b; Lane et al., 2013).

\subsection{Field work and varve counting}

During a coring expedition in 2009 seven new and parallel core sequences were retrieved from the deepest part of the lake basin using a UWITEC piston corer. The maximum distance between individual coring sites was $20 \mathrm{~m}$. These sediment profiles, labelled as cores MFM09-A to MFM09-G, were split, imaged, described and correlated. Each of this sediment profiles consists of a sequence of 5-6 up to $2 \mathrm{~m}$ long core segments, typically with gaps of a few $\mathrm{cm}$ between each individual core. Two sediment profiles were selected for thin sections analyses: core MFM09-A (11.50 m long) and core MFM09-D (10.58 m long). Core A was recovered from the water/sediment interface, whereas core $D$ starts $70 \mathrm{~cm}$ below. $A$ composite profile (MFM09; $11.71 \mathrm{~m}$ long) was constructed through detailed correlation based on macroscopic and microscopic marker layers. Martin-Puertas et al. (2012) used the same marker layers to correlate the new sediment profile with a previous profile MFM- 6 (Brauer et al., 1999; Brauer et al., 2000a). The new continuous sediment record (MFM09) so far has been investigated in particular for Holocene climate and environment changes (Martin-Puertas et al., 2012a).

Varve counting was carried out on a continuous series of thin sections ( $100 \times 35 \mathrm{~mm}$, with 2 $\mathrm{cm}$ overlaps) using a petrographic microscope under parallel and polarized light (Brauer et al., 1999; Martin-Puertas et al., 2012a). Varve counting involved thickness measurements for each varve at higher microscopic magnification (100x). In order to assess the individual error, varve counting was realized twice by the same counter.

\subsection{Cryptotephra investigations}

The entire core sequence MFM09-D was investigated for the presence of cryptotephra following the non-destructive density floatation method of Turney (1998); Blockley et al. (2005). Tephra glass shards within the $1.95-2.55 \mathrm{~g} / \mathrm{cm}^{3}$ residue (and also $>2.55 \mathrm{~g} / \mathrm{cm}^{3}$ for low resolution samples) were identified and absolute numbers counted under high powered polarised light microscopy, then quantified as shards per gram of dry sediment $(\mathrm{s} / \mathrm{g})$. Where tephra glass shards were discovered in initial low-resolution contiguous samples, these 10 $\mathrm{cm}$ lengths were re-investigated at $1 \mathrm{~cm}$ resolution to better define the location of the tephra layer. Where possible, thin section inspection of the cores was then used to locate the tephra layer to its exact varve position. All Tephra layers are given sample codes based 
upon their first occurrence depth below lake floor $(\mathrm{cm})$ and these are used throughout the manuscript.

\subsection{Geochemical analysis}

In order to concentrate glass shards for geochemical analysis, they were picked from samples under high-powered microscopy, using a gas chromatography syringe (Lane et al., 2014). The tephra shards were then mounted in epoxy resin, sectioned and polished for geochemical analysis. Major and minor element concentrations were measured by wavelength dispersive electron probe micro-analysis (WDS-EMPA), using the Jeol JXA 8600 microprobe in the Research Laboratory for Archaeology, University of Oxford. Instrument operating conditions: $15 \mathrm{keV}$ accelerating voltage, $6 \mathrm{nA}$ current, $10 \mu \mathrm{m}$ beam diameter and 10-30 s peak count times. The ATHO-g (rhyolitic) and StHs6/80-g (andesitic) MPI-DING fused volcanic glass secondary standards (Jochum et al., 2006) were analysed with the tephra samples to monitor instrument precision and accuracy (Supplementary Information Table $\mathrm{S} 2)$. Major element $\left(\mathrm{SiO}_{2}, \mathrm{Al}_{2} \mathrm{O}_{3}, \mathrm{FeOtot}, \mathrm{CaO}, \mathrm{Na}_{2} \mathrm{O}, \mathrm{K}_{2} \mathrm{O}\right)$ precision on secondary standard analyses ranges from $<1$ to $<10 \%$ (at $2 \sigma$ ), precision for the less abundant elements varies between $10-30 \%$.

Trace element compositions were measured by laser ablation inductively coupled plasma mass spectrometry (LA-ICP-MS), using the Agilent 7500 ICP-MS coupled to a $193 \mathrm{~nm}$ Resonetics ArF eximer laser ablation system, in the Department of Earth Sciences, Royal Holloway University of London. Analytical protocols and data quantification followed those described in Tomlinson et al. (2010): a $5 \mathrm{~Hz}$ repetition rate and 40 second sample and gas blank count times were used. NIST 612 was used as a standard for calibration, with ${ }^{29} \mathrm{Si}$ as the internal standard element having been previously measured by WDS-EPMA within each individual grain. Laser spot sizes of between $25 \mu \mathrm{m}$ and $34 \mu \mathrm{m}$ were used according to the size of the glass shards. For consistency with WDS-EMPA, the ATHO-g and StHs6/80-g MPIDING secondary glass standards were used to monitor precision and accuracy (Supplementary Information Table S2). Precision on secondary standard analyses (at 2 $\sigma$ ) averages $<10 \%$ for all elements, with the exception of Sm, Dy and $\mathrm{Yb},<18 \%$, which are present in very low concentrations. Due to small grain sizes and low glass shard concentrations (section 3.1), not all samples were successfully analysed by LA-ICP-MS.

\section{Results}

The uppermost two meters of the new core MFM09 are not laminated, but varves are wellpreserved over most of the lower part of the record. This confirms reports from the previous MFM-6 core (Brauer et al., 2000).

\subsection{Varve chronology}

In this study, we present a new and slightly revised varve chronology for MFM labelled as MFM2015 chronology. This chronology has been established for the latest MFM composite profile (MFM-09) and is for the Holocene part (0-753 cm sediment depth) identical with the MFM2012 chronology (Martin-Puertas et al. (2012a). For the interval from the Laacher See Tephra (LST; 12,880 varve yrs BP, late Allerød) up to the early Holocene Ulmener Maar tephra (UMT; 11,000 varve yrs BP) the chronology is identical to the MFM- 6 chronology (Brauer et al., 1999). Varve ages were transferred from the MFM-6 to the MFM-09 core sequence (753-876 cm depth interval) through correlating a series of macroscopic and microscopic marker layers. The revision only affects the older part of the lateglacial 
sediment interval below the LST down to the onset of distinct and continuous varve preservation (876-1073 cm sediment depth, Fig. 2-3). Because of the better varve preservation in this section of the new composite MFM-09 profile this interval has been recounted and revealed in total $1350 \pm 50$ varves, i.e. 100 varves more than in the previous MFM-6 chronology (Fig. 3). This resulted in a revised age for the onset of continuous varve preservation at $14,230 \pm 90$ varve yrs BP. Absent or very poor varve preservation prevented from varve counting in the early Lateglacial interstadial. The duration of ca. 400 years from the beginning of the Lateglacial interstadial, defined as Meiendorf pollen zone by Litt and Stebich (1999), thus had to be extrapolated based on measured varve thickness in the lowermost interval of continuous varve occurrence (Fig. 3).

The error estimate for the new MFM2015 chronology adds \pm 50 varve yrs derived from multiple counting of the revised section to the previously defined error estimate for the LST $(12,880 \pm 40$ varve yrs BP; Lane et al., 2013). The resulting error estimate for the age of the onset of continuous varve formation in MFM $(14,230 \pm 90$ varve yrs BP) is considered a minimum error because the counted interval includes a small slumped section which is also present in the MFM- 6 sediment profile (Brauer et al., 2000b). The duration of this section (110 estimated varve years) has been calculated by interpolation and adopted from the MFM-6 chronology (Brauer et al., 2000b). A reliable error estimate for this interpolated interval is difficult to determine (Brauer et al., 2014).

\subsection{Tephrostratigraphy and correlation of tephra layers}

Figure 2 shows the results of cryptotephra investigations in Meerfelder Maar. Throughout most of the core tephra glass shards were found in discrete layers, or restricted zones, with low concentrations ( $<200 \mathrm{~s} / \mathrm{g}$ ). However, between $\sim 900-700 \mathrm{~cm}$ depth, tephra counts are much higher. This zone of increased shard counts begins with the visible ( $>10 \mathrm{~cm}$ thick) Laacher See Tephra layer (MFM_876), and continues through the Younger Dryas sediments. No evidence of background tephra material, from the Meerfelder Maar crater itself, was observed. Samples of Meerfelder Maar tephra reveal shards densely packed with microlites and visually very different to those observed reported in this study. In total, 17 layers containing tephra were studied at $1 \mathrm{~cm}$ resolution, and these are labelled in Figure 2 according to their depth. Beginning at the base of the core, the size (longest axis length), appearance and chemical composition (normalised values) of each of these tephra layers is described here.

Of the 17 tephra samples studied from the Meerfelder Maar sediments, only four can be confidently correlated to known eruption events and one other correlated to a volcanic source (Table 3, Figures 4 - 5). Section 3.2 discusses the issues and difficulties involved in correlating some of the unidentified tephra layers.

MFM_T1137 (1137 cm; before the onset of continuous varve formation):

The oldest tephra layer in the Meerfelder Maar core, with a concentration of $50 \mathrm{~s} / \mathrm{g}$, shows both morphological and chemical variability. Most of the glass shards are thin, with curvilinear form representing bubble-wall junctions. Longest axis lengths are $<150 \mu \mathrm{m}$. However there are also a number of distinct and smaller glass shards, showing either deformed and elongated vesicle textures, a high number of un-expanded vesicles and also some containing microlites $(<5 \mu \mathrm{m})$. 
Four glass shards were analysed on the microprobe, all of rhyolitic composition (Table 1 and Figure 4a). Three of these have 71.2-71.8 wt\% $\mathrm{SiO}_{2}, 13.9-14.9 \mathrm{wt} \% \mathrm{Al}_{2} \mathrm{O}_{3}, 1.8-2.3 \mathrm{wt} \% \mathrm{CaO}$ 2.7-3.9 wt\% $\mathrm{Na}_{2} \mathrm{O}, 3.5-3.9 \mathrm{wt} \% \mathrm{~K}_{2} \mathrm{O}$ and are likely to have derived from the same eruption event. The fourth shard has a much higher $\mathrm{SiO}_{2}$ content of $77.1 \%$ and lower values of $\mathrm{FeO}$, $\mathrm{MgO}$ and $\mathrm{CaO}$.

MFM_T1130 (1130 cm; before the onset of continuous varve formation):

MFM_T1130 has only $32 \mathrm{~s} / \mathrm{g}$, which is the lowest concentration in the core. Glass shards are dominantly $<120 \mu \mathrm{m}$, blocky in appearance and have no internal vesicles, however a small number of 120-150 $\mu \mathrm{m}$ plate-like glass shards were noted as well as two highly vesicular shards $<40 \mu \mathrm{m}$. Of the nine shards analysed by WDS-EPMA, four show a homogeneous phonolitic composition, with 57.4-60.8 wt\% $\mathrm{SiO}_{2}, 20.0-20.7$ wt\% $\mathrm{Al}_{2} \mathrm{O}_{3}$, 2.1-2.6 wt\% FeO, 5.1$6.2 \mathrm{wt} \% \mathrm{Na}_{2} \mathrm{O}$ and 7.5-8.9 wt\% $\mathrm{K}_{2} \mathrm{O}$. This composition is consistent with that of MFM_T876. The remaining shards show a range of rhyolitic compositions (Table 1 and Figure 4a), which are not interpreted to represent a single volcanic event.

MFM_T1072 (1072 cm; 14,230 \pm 90 varve yrs BP):

This tephra material is found in the first sample directly after the onset of continuous varve preservation. Tephra glass shards in MFM_T1072 are all $<70 \mu \mathrm{m}$ and have irregular vesicular forms displaying closed, expanded and elongated vesicles. Glass shard concentrations were $113 \mathrm{~s} / \mathrm{g}$. With the exception of three rhyolitic outliers, the glass shards from MFM_T1072 show a bi-modal phono-trachyte to trachyte composition (Table 1, Figure 4). The phono-trachyte end member has 57.3-59.3 wt\% $\mathrm{SiO}_{2}, 4.2-5.3 \mathrm{wt} \% \mathrm{FeO}, 0.9-1.5 \mathrm{wt} \%$ $\mathrm{CaO}, 3.4-3.8 \mathrm{wt} \% \mathrm{Na}_{2} \mathrm{O}$ and 7.8-8.9 wt\% $\mathrm{K}_{2} \mathrm{O}$. The trachyte end-member has $61.3-62.0 \mathrm{wt} \%$ $\mathrm{SiO}_{2}$, 2.5-3.3 wt\% $\mathrm{FeO}, 2.2-2.5$ wt\% $\mathrm{CaO}, 3.5-4.3$ wt\% $\mathrm{Na}_{2} \mathrm{O}$ and 8.7-9.4 wt\% $\mathrm{K}_{2} \mathrm{O}$. Trace element analysis of these two end-member compositions show consistent values of $\sim 320$ ppm Rb, 30ppm Y, 300 ppm Zr, $\sim 45$ ppm Nb and clear bi-modality in Sr (trachy-phonolite $\sim 900$ ppm, trachyte 460 ppm) and Ba (phono-trachyte 1570 ppm, trachyte 780 ppm). As shown in Figure 4b, MFM_T1072 correlates to the Neapolitan Yellow Tuff; generated by a Plinian eruption from the Campi Flegrei Volcanic Zone (CFVZ) in Southern Italy 14.2 ka BP (Section 4.3).

The CFVZ was highly active during the Lateglacial and many tephra layers were widely dispersed that have trachyte to phonolite glass compositions (Siani et al., 2004; Wulf et al., 2004; Smith et al., 2011). The Neapolitan Yellow Tuff can be distinguished from other CFVZ eruptions as it straddles the phono-trachyte boundary (Figure 4a) and is composed of two members: a compositionally bi-modal lower member and an upper member that spans the full compositional range between the two lower member populations (Tomlinson et al., 2012). MFM_T1067 is chemically correlated to the bi-modal lower member of the Neapolitan Yellow Tuff, which is consistent with other distal occurrences in Austria and Slovenia, where only the lower member is found (Schmidt et al., 2002; Lane et al., 2011a).

MFM_T876 (876 cm; 12,880 varve yrs BP):

This visible tephra layer has been previously correlated to the LST (Brauer et al., 1999) on the basis of its stratigraphic position and appearance in thin section. The MFM09 cores preserve $5 \mathrm{~cm}$ of tephra, with a sharp basal contact at $876 \mathrm{~cm}$. Glass shards have very high vesicularity, characteristic of the LST, which appears like microscopic pumices, with grain sizes $<300 \mu \mathrm{m}$. The $10 \mathrm{~cm}$ layer has a homogeneous phonolite composition (Figure 4c), with 
58.9-63.2 wt\% $\mathrm{SiO}_{2}, 18.8-21.2 \mathrm{wt} \% \mathrm{Al}_{2} \mathrm{O}_{3}, 1.1-2.3 \mathrm{wt} \% \mathrm{CaO}$ and variable alkali contents, 4.9$9.3 \mathrm{wt} \% \mathrm{Na}_{2} \mathrm{O}$ and 6.6-9.0 wt\% $\mathrm{K}_{2} \mathrm{O}$. Trace element analysis of two shards also show compositions of 183 and 198 ppm Rb, 224 and 334 ppm Sr, 15 and 16 ppm Y, 452 and 466 ppm Zr and 93 and 104 ppm La (Table 2; Figure 4c). Comparison to compositional data generated on pumice glasses from proximal LST deposits shows that MFM_T876 correlates to the Upper phase of the LST, which is the only phase believed to have distributed ash to the west of the eruption centre in the East Eifel region (van den Bogaard and Schmincke, 1985; Riede et al., 2011).

Tephra from the LST continued to be input into the Meerfelder Maar sediments for about 1600 years after the eruption. Concentrations of morphologically and geochemically identical tephra glass shards are seen to decrease upward within the $\sim 70 \mathrm{~cm}$ above the appearance of the LST at $876 \mathrm{~cm}$, and trace amounts (>100 s/g) are present throughout the full length of the Younger Dryas sediments.

MFM_T801 (801 cm; 12,140 varve yrs BP):

High concentrations of glass shards, $7060 \mathrm{~s} / \mathrm{g}$, were found at $801-775.5 \mathrm{~cm}$ depth. The layer is composed of colourless shards with plate-like and curvilinear forms, $<200 \mu \mathrm{m}$, as well as light to dark brown shards, $<130 \mu \mathrm{m}$, with many expanded and some elongate vesicles.

Excluding one shard (EPMA \#29, Table 1) that has a phonolitic composition consistent with MFM_T876, major and trace element analysis of MFM_T801 ( $n=40$ and $n=15$ respectively) show a bi-modal composition. One end member shows a trend from basaltic-andesite to andesite (52.8-61.9 wt\% $\mathrm{SiO}_{2}, 8.4-13.1 \mathrm{wt} \% \mathrm{FeO}, 4.9-10.5 \mathrm{wt} \% \mathrm{CaO}$ and 1.1-2.4 wt\% $\mathrm{K}_{2} \mathrm{O}$ ) and the second end-member is a homogeneous rhyolite (71.8-72.5 wt\% $\mathrm{SiO}_{2}, 3.6-4.0 \mathrm{wt} \%$, $\mathrm{FeO}, 1.3-1.5 \mathrm{wt} \% \mathrm{CaO}$ and 4.5-5.5 wt\% $\mathrm{K}_{2} \mathrm{O}$ ). Trace element compositions also describe bimodality, with approximately 80-90 ppm Rb, 850-950 ppm Zr and 120-130 ppm Nb in the rhyolitic end member and approximately 30-50 ppm Rb, 350-560 ppm Zr and 50-80 ppm Nb in the basaltic-andesite member (Figure 4d).

Bimodal MFM_T801 is correlated to the rhyolitic and intermediate phases of the Vedde Ash (Figure 4d) (Lane et al., 2013), however the Vedde Ash basaltic end-member was not found in MFM. The Vedde Ash is an important tephra isochron found widely across Europe and the North Atlantic, erupted from the Katla volcano in Iceland, occurring midway through the Younger Dryas in many European sediment records (Mangerud et al., 1984; Lane et al., 2012b), and within Greenland Stadial 1 in the NGRIP ice core (Mortensen et al., 2005; Rasmussen et al., 2006). MFM_T801 represents the first appearance within the record of any shards with Katla Vedde-type composition.

MFM_T711 (711cm; 11,000 varve years BP):

A tephra layer found at $710-711 \mathrm{~cm}$ depth has previously been correlated to the Ulmener Maar tephra, dated to 11,000 varve years BP (Zolitschka et al., 1995; Brauer et al., 1999), on the basis of its appearance and stratigraphic position. This tephra layer contains no typical aphyric tephra glass shards, but rather crystal-rich juvenile fragments, which are distinctively isotropic (glassy) but range in shape from rounded to sub-angular, indicating formation within a very crystal rich melt. Volcanic crystals (pyroxene, olivine, mica, oxide minerals) and lithic fragments are also present within the denser fraction of the separated sample. Grain sizes of all fractions are $<90 \mu \mathrm{m}$. This texture is consistent with other samples 
of the UMT taken from proximal outcrops, where pumice clasts are holocrystalline. In the absence of areas of aphyric glass, no chemical analysis was made on this tephra layer.

MFM_T687 (687 cm; 10,648 varve yrs BP) \& MFM_T685 (685 cm; 10,619 varve yrs BP):

Tephra concentrations decrease dramatically at $\sim 730 \mathrm{~cm}$ during the first centuries of the Holocene (Figure 2) and associated with climatic amelioration and resultant increase in vegetation cover and stabilisation of the landscape in and around the Meerfelder Maar catchment. The first appearance of tephra glass shards in the Holocene is of concentrations of $3-232 \mathrm{~s} / \mathrm{g}$ found between 678 and $667 \mathrm{~cm}$. From this zone of tephra, two $1 \mathrm{~cm}$ samples with the highest shard concentrations were picked out for analysis. Both MFM_T687 (232 s/g) and MFM_T685 (113 s/g) are dominated by highly vesicular tephra shards, <70 $\mu \mathrm{m}$, which have both morphological and chemical affinity to MFM_T876 (Figure 4). In both samples, a smaller number of $<120 \mu \mathrm{m}$ plate-like shards are also present, and these are represented by a number of rhyolitic major and trace element analyses from MFM_T685.

Thin section analysis of the sediments around $685-687 \mathrm{~cm}$ revealed a number of fine minerogenic detrital layers, which are interpreted as extreme runoff events (Martin-Puertas et al., 2012b; van Geel et al., 2013). It suggests these layers are not formed from volcanic airfall events, but from reworking of older tephra-bearing sediment within the Meerfelder Maar catchment.

MFM_T573 (573 cm; 7,744 varve yrs BP):

Glass shard concentrations in MFM_T573 are $92 \mathrm{~s} / \mathrm{g}$. Tephra glass shards are $<80 \mu \mathrm{m}$ and fairly blocky in shape, with concave edges from fragmented vesicle walls. Four analyses were achieved on these small shards and reveal peralkaline pantellerite compositions (following Macdonald, 1974), with 69-75 wt\% $\mathrm{SiO}_{2}, 6.1-7.5$ wt $\% \mathrm{Al}_{2} \mathrm{O}_{3}, 3.0-4.7$ wt \% FeO, 1.6-1.8 wt \% MgO, 1.8-3.0 wt\% $\mathrm{CaO}$, 5.6-6.1 wt\% $\mathrm{Na}_{2} \mathrm{O}$ and 6.5-8.7 wt\% $\mathrm{K}_{2} \mathrm{O}$. Just one LAICP-MS analysis was made on a pantellerite glass shard and this has approximately $220 \mathrm{ppm}$ $\mathrm{Rb}, 30 \mathrm{ppm} \mathrm{Zr,} 11 \mathrm{ppm} \mathrm{Nb}$ and $349 \mathrm{ppm}$ Ba (Table 2). Also within this sample there are a number of highly vesicular shards, $<200 \mu \mathrm{m}$, of phonolitic composition consistent with MFM_T876 (MFM_T573, \#1-8 in Table 1) and two more platy shards (MFM_T573, \#9-10 Table 1) with rhyolitic major, minor and trace element compositions consistent with MFM_T801.

Pantellerite tephra are rare and commonly come from volcanic centres associated with continental or ocean ridge rifting (Civetta et al., 1984). In Europe and the North Atlantic, Holocene Pantellerites have been reported from Pantelleria Island in the Mediterranean (Mahood and Hildreth, 1986; Magny et al., 2011) and Jan Mayen in the North Atlantic (Lacasse and Garbe-Schönberg, 2001). Terceira volcano in the Azores has also erupted peralkaline trachytes (Gertisser et al., 2010). However, the available glass data from these volcanic centres does not correlate with MFM_T573 (Figure 4e), therefore the source eruption remains unidentified.

MFM_T568 (568 cm; 7,633 varve yrs BP):

Distinctly plate-like shards, $<50 \mu \mathrm{m}$ in size, characterise MFM_T568. A concentration of 75 $\mathrm{s} / \mathrm{g}$ was calculated from a small sample size of only $0.04 \mathrm{~g}$, therefore although replicable; only 3 shards were counted in the original $1 \mathrm{~cm}$ sample. A single shard was analysed by WDS-EPMA and had a rhyolitic composition consistent with MFM_T801. 
MFM_T552 (552cm; 7,314 varve yrs BP), MFM_T550 (550 cm; 7,279 varve yrs BP)\& MFM_T548 (548 cm; 7,245 varve yrs BP):

Low concentrations $(<20 \mathrm{~s} / \mathrm{g})$ of tephra were observed in the low resolution $(10 \mathrm{~cm})$ scans between 484 and $540 \mathrm{~cm}$ depth (Figure 2). At $1 \mathrm{~cm}$ resolution, tephra was seen to be present through much of this depth, again in concentrations $<20 \mathrm{~s} / \mathrm{g}$. The three samples with the highest shard concentrations were found at 527-548 cm $(50 \mathrm{~s} / \mathrm{g}), 529-550 \mathrm{~cm}(38$ $\mathrm{s} / \mathrm{g})$ and $531-552 \mathrm{~cm}(61 \mathrm{~s} / \mathrm{g})$. These three samples were selected for analysis. All three layers contained equant and platy tephra shards with curvilinear surfaces, $<90 \mu \mathrm{m}$. MFM_T552 and MFM_T548 also contained $<40 \mu \mathrm{m}$ shards with many expanded vesicles. EMPA was only possible on five shards from across these three samples and did not reveal any consistent chemical compositions. The glass shard in MFM_T552 is an alkali-trachyte, which plots close to the composition of MFM_T1067 on elemental bi-plots (Figure 4a). Two shards, one in each of MFM_T550 and MFM_T548, correlate to MFM_T876. A rhyolitic shard was also found in MFM_T550 and another alkali-trachytic shard was measured in MFM_T548.

MFM_T334 (334 cm; 3,382 varve yrs BP):

Tephra glass shards in MFM_T334 are $<50 \mu \mathrm{m}$ in their longest axis and very thin, with curved shapes and closed circular and irregular vesicles. Very fine microlites $(<10 \mu \mathrm{m})$ were noted in a couple of shards. Glass shard concentrations were $113 \mathrm{~s} / \mathrm{g}$. Three trachytic glass shards were analysed from this sample, with approximately $62.5-64.6 \% \mathrm{SiO}_{2}, 16.6-18.0 \mathrm{wt}$ $\% \mathrm{Al}_{2} \mathrm{O}_{3}, 3.9-4.4 \mathrm{wt} \% \mathrm{FeO}, 7.3-8.3 \mathrm{wt} \% \mathrm{Na}_{2} \mathrm{O}$ and 4.9-5 wt \% $\mathrm{K}_{2} \mathrm{O}$. One shard is distinct as it has a higher $\mathrm{CaO}$ content of $1.7 \mathrm{wt} \%$ and this differentiation is also evident in the trace element composition (Tables 1 and 2). As apparent in Figure 4e the compositions of the remaining two shards from MFM_T334 show some similarity to Late Holocene tephra layers found in Western Ireland, in the sites of Loch Mor, Inis Oirr (Chambers et al., 2004) and Derrycunihy (Reilly and Mitchell, 2014). The tephra layers in Loch Mor have been correlated to trachytic eruptions from Jan Mayen, however they are much younger than MFM_T334, being dated to between AD 1400 and AD 1915. At Derrycunihy, tephra with a similar composition has been tentatively correlated to the Mt Furnas volcano in the Azores and this may in fact offer a better correlation for many of the cryptotephra currently correlated to Jan Mayen in Western Ireland (Reilly and Mitchell, 2014; Johannesson, in press). The available summary glass data from Mt Furnas is plotted in Fig. 4 and it is anticipated that forthcoming data will secure the correlation of MFM_T334 to an eruption of this Azores volcano.

\section{MFM_T325 (325cm; 3,230 varve yrs BP):}

Thin, curvilinear glass shards with open vesicles, $<90 \mu \mathrm{m}$ long, were found in a concentration of $100 \mathrm{~s} / \mathrm{g}$ at $325-320 \mathrm{~cm}$. However, no shards were successfully recovered for chemical analysis from this layer (Section 3.2).

MFM_T322 (322 cm; 3,162 varve yrs BP):

This tephra layer contained highly vesicular shards, $<60 \mu \mathrm{m}$, similar in morphology to the LST. A glass shard concentration of $63 \mathrm{~s} / \mathrm{g}$ was found. Again, extraction of tephra shards from this layer for geochemical analysis was unsuccessful.

MFM_T238 (238 cm; 2,020 varve yrs BP): 
400 Tephra glass shard concentrations of $90 \mathrm{~s} / \mathrm{g}$ and $72 \mathrm{~s} / \mathrm{g}$ were found in $1 \mathrm{~cm}$ samples from

$238-239 \mathrm{~cm}$ and $237-238 \mathrm{~cm}$, respectively. Across these two samples the shard morphologies were very similar, with large $(<150 \mu \mathrm{m})$ irregular forms, containing either small closed circular vesicles or expanded vesicle forms. Due to the high organic content of these samples, the absolute number of shards observed in each $1 \mathrm{~cm}$ sample was 13 and 9, respectively; these samples were therefore combined for geochemical analysis. The two resultant WDS-EPMA analyses reveal two different trachytic compositions, as evident in Table 1 and Figure $4 a$.

\subsection{Unidentified tephra samples}

12 of the cryptotephra layers located within MFM remain unattributed to a volcanic source or a specific eruption event. The reasons for this include insufficient chemical analysis due to the small shard concentrations (e.g. MFM_T568), heterogeneous compositions (e.g. MFM_T1130) and a lack of correlative data (e.g. MFM_T334). Tephra shards with compositions that correlate to the Vedde Ash or Laacher See Tephra (MFM_T889 or MFM_T801) are found intermittently throughout the record and these may indicate redeposition of tephra from within the maar catchment. In the case of MFM_T687 and MFM_T685, detrital layers have been identified by thin section analysis.

Nevertheless, multiple eruptions from Katla have been shown to deliver compositionally similar tephra layers to northern Europe (Wastegård, 2002; Koren et al., 2008; Matthews et al., 2011; Lane et al., 2012b) and this could also explain the presence of tephra shards with a Vedde Ash-like rhyolite composition. MFM_T568 for example, which is dated to ca 7617 varve yrs BP may be correlated to the Suduroy tephra, described by Wastegård (2002) from the Faroe Isles and dated to 8308 - 7868 cal years BP (7240 \pm 95 14C years, calibrated in OxCal v4.1 using the IntCal13 calibration curve (Bronk Ramsey, 2001; Reimer et al., 2013). Correlations based upon a few isolated shards are however, not robust. This is exemplified by the scatter within some samples (e.g.MFM_T573), which illustrates the need for multiple analyses to build a complete picture of a tephra sample's chemical composition. Such mixed populations could of course come from more than one eruption event, closely spaced in time. Samples were taken at $1 \mathrm{~cm}$ resolution, which represents approximately $20-30$ years of sedimentation.

Finally, it is of course possible that some tephra layers were missed altogether, either due to the presence of $\mathrm{cm}$-scale gaps between individual core segments of MFM09, or due to patchy preservation within the lake floor sediments.

\section{Discussion}

\subsection{A new tephrostratotype sequence for Europe}

The preservation of multiple tephra layers within an annually resolved archive establishes the Meerfelder Maar Lateglacial sediment record as a key tephrostratotype site (Figure 5). By providing high precision varve ages for co-located tephra layers from different volcanic centres, Meerfelder Maar provides an important chronological contribution to the existing tephrostratigraphic framework that connects sites from the North Atlantic to the Mediterranean (Davies et al., 2012; Lane et al., 2012a) 
The four tephra layers successfully identified in Meerfelder Maar record eruptions from three different volcanic centres: the nearby Eifel volcanic zone (West and East Eifel); Katla, in the eastern volcanic zone of Iceland; Campi Flegrei volcanic zone, in Southern Italy. With the exception of the Ulmener maar tephra, which is less widespread, the tephra layers facilitate direct correlations between a large number of palaeoenvironmental archives from across Europe and the North Atlantic (Figure 6).

Of particular note is the discovery of the Neapolitan Yellow Tuff in Western Germany, 1200 $\mathrm{km}$ from the source in Campi Flegrei. The Neapolitan Yellow Tuff isochron allows the Meerfelder Maar record to be directly linked to the varve record of Lago Grande di Monticchio in Southern Italy (Wulf et al., 2004) (Figure 6), a discontinuously varved sediment record of Mediterranean environmental change spanning approximately $133 \mathrm{ka}$ (Brauer et al., 2007). This discovery therefore highlights the potential for making highprecision comparisons of the phasing of environmental transitions between Lateglacial sediment records from Central Europe and the Mediterranean.

\subsection{Addressing the unknowns}

A number of important points with regards to the limitations of characterising cryptotephra layers are highlighted by the number of unattributed cryptotephra layers in Meerfelder Maar (13 of 17).

Primarily, it is evident that our existing knowledge of widespread tephra layers is incomplete, even for a region and time period as well-studied as the European Lateglacial and Holocene. In the case of some layers, e.g. MFM_T334, volcanic sources can be tentatively attributed, but for others no correlation is suggested. The addition of 51 welldefined tephra isochrons (16 Icelandic, 17 Italian, 9 Massif Central, 3 Eifel, 2 Hellenic Arc, 3 Anatolian and 1 Carpathian) to the latest INTIMATE event stratigraphy back to 60,000 years BP (Blockley et al., 2014) illustrates the focus of European cryptotephra research on archives dominated by Icelandic and Italian tephra layers. This in part reflects the prevalence of far travelled tephra from these volcanic regions during the Lateglacial, but also highlights that detailed studies, generating compatible tephra glass shard compositional data, are much needed from other volcanic regions of Europe (e.g. the Massif Central, Azores).

Secondly, the majority of unattributed tephra layers contain low concentrations of glass shards of variable rhyolitic compositions (e.g. MFM_T1137, MFM_T 1130, MFM_T573, MFM_T568, MFM_T550; outliers in MFM_T1072). Rhyolitic magmas are common in the European record, being frequently generated from volcanoes in Iceland, the Aegean, the Aeolian Islands, the Carpathians and Central Anatolia (Tomlinson et al., in press). Typically rhyolites are erupted during highly explosive eruptions (sub-plinian to plinian) and are characterised by bubble-wall to plate-like glass shards. This material is therefore able to be transported extreme distances in the atmosphere and the sources for these tephra shards may be far beyond the volcanic centres of Europe. Whilst comparisons to all available datasets have been made in attempt to identify the unattributed tephra shards from Meerfelder Maar, the small concentrations and often variable compositions suggest that robust correlations are not likely for many of the layers. Trace element analyses could be used to help narrow down the source region of these glasses (e.g.Tomlinson et al., in press), however larger datasets would be needed than are available here.

Finally, the importance of both robust compositional characterisation and a good understanding of taphonomy of cryptotephra layers are highlighted by this study. Working 
in the undisturbed laminated sections of the Meerfelder Maar sequence, for which detailed thin section micromorphology has been carried out, has allowed the recognition of at least one area of the core where tephra has been reworked and later re-deposited within the lake sediments. Thin section analyses confirmed that tephra shards, found in concentrations of $<232 \mathrm{~s} / \mathrm{g}$ between $690-684 \mathrm{~cm}$, are located coincident with fine detrital material, indicating these are reworked deposits (section 3.1). This was supported by EMPA of MFM_T687 and MFM_T685, which turned out to be composed of tephra glass shards from the LST and VA eruptions. Critically, this reworking event was only confirmed by the thin section work, whereas within a less well-studied sediment sequence, the layers may have been considered as genuine air fall tephra layers. Indeed, it may be the case that some of the remaining Holocene tephra layers in the Meerfelder cores could also represent reworked wind-blown or in-washed tephra.

\subsection{Improved dating of eruptions and events}

Table 3 provides varve age estimates for the Ulmener Maar tephra (UMT), Vedde Ash (VA), Laacher See tephra (LST) and Neapolitan Yellow Tuff (NYT), all of which were found within the varved portion of the Meerfelder Maar record. These ages agree with independently generated age estimates for each of the eruptions and in the case of the NYT significantly improve on the existing dating precision. The Neapolitan Yellow Tuff has been dated by the ${ }^{40} \mathrm{Ar} /{ }^{39} \mathrm{Ar}$ method to $14.9 \pm 0.4 \mathrm{ka}$ (Deino et al., 2004). This age, however, is older than ages obtained by radiocarbon dating of proximal and distal material associated with this ash (Blockley et al., (2008) and predates an IntCal-13 (Reimer et al., 2013) modelled date of 14,366 - 14,022 cal BP by (Bronk Ramsey et al., in press-a), obtained by Bayesian combination of radiocarbon age-estimates from multiple sites. The Neapolitan Yellow Tuff is also located in Lago Grande di Monticchio, southern Italy, where it is varve dated to 14,120 \pm 710 yrs BP (Wulf et al., 2008). The revised Meerfelder Maar chronology (MFM-2014) presented in this paper dates the NYT at $14,230 \pm 90$ varve yrs BP. The NYT in MFM is located at the boundary between discontinuous and poor varve preservation of the early Lateglacial interstadial and continuous preservation of distinct varves that is related to the stabilisation of the catchment by vegetation cover. Differential dating between the most important Lateglacial and early Holocene tephra layers in MFM reveals $1350 \pm 50$ varve yrs between the NYT and the LST, $740 \pm 40$ varve yrs between the LST and the VA, and $1140 \pm$ 40 varve yrs between the VA and the UMT. This information can be imported into other archives containing two or more of these tephra layers and used to increase age model precision and accuracy.

Varve counting between each of the tephra layers and regional biostratigraphical boundaries preceding and post-dating them, helps to explore the timing and duration of some the local palaeoenvironmental responses to widely observed climatic transitions (Table 3). These differential ages can be compared to other high resolution archives containing the same tephra layers and precise assessments of the synchronicity of local environmental transitions can be made. Whilst some tephra layers have a limited dispersal, such as the UMT, which occurs 590 years after the transition into the Holocene, others such as the VA, can be correlated over continental distances.

The relative durations of GS-1 (Greenland) and the Younger Dryas (Europe) have been discussed previously (Brauer et al., 1999; Brauer et al., 2008; Muscheler et al., 2008; Lane et al., 2011b; Lohne et al., 2013), however, even annually resolved records suffer from decadal to centennial-scale uncertainties that have prevented precise comparisons of abrupt 
transitions. The Vedde Ash provides a means of directly synchronising the Meerfelder varve chronology with GICC05, facilitating precise comparison of the timing of the Younger Dryas in Meerfelder Maar and GS-1 in NGRIP for the first time (Table 3). The Younger Dryas in Meerfelder Maar (12,679-11,590 varve years BP) began 539 varve years before the deposition of the Vedde Ash and the transition into the Holocene occurred 550 years afterwards (Table 3). These transitions are defined by major biostratigraphical boundaries (Litt and Stebich, 1999) accompanied by abrupt changes in sediment proxies of Meerfelder Maar (Brauer et al., 1999). Using the GICC05 chronology, the GS-1 onset and end in NGRIP are defined by the deuterium excess record $\left(\delta D-8 \delta^{18} \mathrm{O}\right)$, which records abrupt shifts within 1-3 years (Rasmussen et al., 2006; Steffensen et al., 2008). The Vedde Ash (12,171 \pm 114 b2k) in NGRIP lies 725 GICC05 years after the start and 468 GICC05 years prior to the end of GS-1 (Table 3). Accepting both of the chronologies as correct implies that the onset of GS-1 in NGRIP leads the onset of the Younger Dryas in Meerfelder by 186 years and also leads at the start of the Holocene by 132 years. Refining the correlation between these important Lateglacial archives provides a sound platform from which the nature of abrupt climate changes over continental distances and the complexities of environmental proxy sensitivities can be explored (e.g., Lane et al., 2013; Rach et al., 2014)

\section{Conclusions}

Meerfelder Maar now stands out as an important Western European tephrostratotype record for the Lateglacial, providing improved age estimates for, and precise dating of intervals between, tephra layers from three different volcanic centres. Using tephra layers as tie-points between Meerfelder Maar and other archives with annual to decadal-scale chronological resolution has allowed, for the first time, precise layer-counted comparisons between the timing and duration of regional palaeoclimate signals across Europe and the North Atlantic. These results contribute to a better understanding of proxy-response to complex climate forcing events (Lane et al., 2013; Rach et al., 2014). There remains great potential for extending these correlations to other sites containing the Vedde Ash, Laacher See Tephra and Neapolitan Yellow Tuff, as suitably high-resolution palaeoenvironmental records are produced. Furthermore, as detailed records emerge from less well-studied volcanic centres, it is envisaged that some of the unattributed cryptotephra within the Meerfelder Maar record will be identified and will provide additional valuable marker layers for the correlation of Lateglacial and Holocene records.

\section{Acknowledgements}

This study is a contribution to the INTIMATE project (INTegrating Ice core, MArine and TErrestrial records, http://intimate.nbi.ku.dk/); and the climate initiative REKLIM Topic 8 "Abrupt climate change derived from proxy data" of the Helmholtz Association (A.B. and C.M.-P.). The research was funded by the UK Natural Environment Research Council consortium RESET (NE/E015670/1 and NE/E015905/1). C.S.L. was partly funded by the Leverhulme Trust. This study has used infrastructure of the Terrestrial Environmental Observatory (TERENO) of the Helmholtz Association. We thank the Maar Museum in Manderscheid for local support. 
576 Table 1:

577 Single-shard major and minor element oxide compositions (wt\%) for all tephra layers

578 analysed within the Meerfelder Maar record, measured by electron microprobe (section

579 2.3). For samples with $n>12$ analyses, a reduced representative dataset is shown and the full 580 dataset is contained within Supplementary Information (Table S1). Data are presented 581 normalised to water-free compositions, with original totals shown, after filtering points with 582 analytical totals below 94 weight \%. Secondary standard data, which provide a measure of 583 precision and accuracy, are presented within Supplementary Information (Table S2).

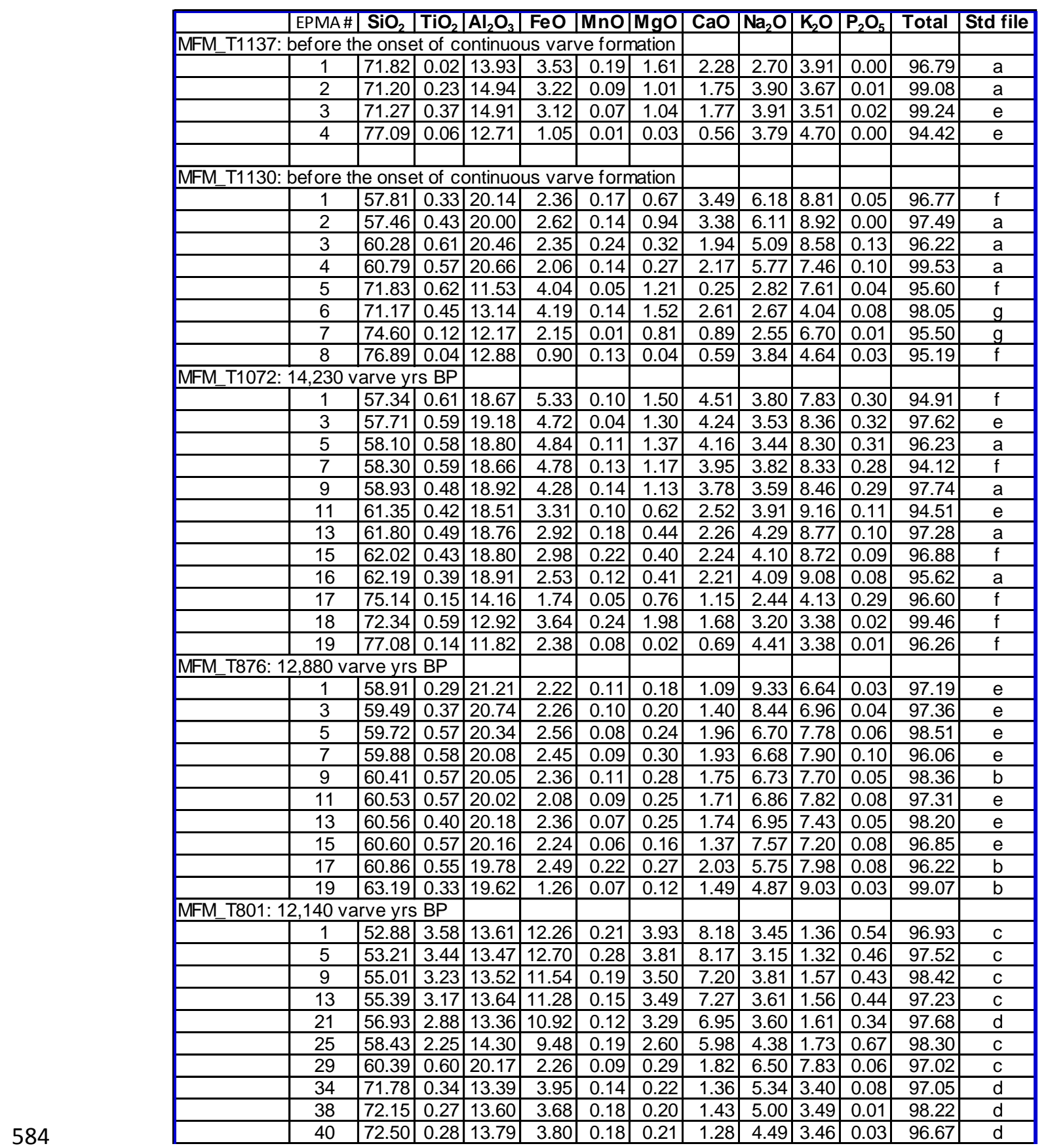




\begin{tabular}{|c|c|c|c|c|c|c|c|c|c|c|c|c|c|}
\hline & & $\mathrm{SiO}_{2}$ & $\mathrm{TiO}_{2}$ & $\mathrm{Al}_{2} \mathrm{O}_{3}$ & $\mathrm{FeO}$ & MnO & $\mathrm{MgO}$ & $\mathrm{CaO}$ & $\mathrm{Na}_{2} \mathrm{O}$ & $\mathrm{K}_{2} \mathrm{O}$ & $\mathrm{P}_{2} \mathrm{O}_{5}$ & Total & Std file \\
\hline \multicolumn{14}{|c|}{\begin{tabular}{l|l|l} 
MFM T687:10,648 varve yrs BP & \\
\end{tabular}} \\
\hline & 1 & 58.90 & 0.92 & 20.10 & 2.87 & 0.03 & 0.33 & 2.42 & 6.54 & 7.78 & 0.12 & 96.57 & $\mathrm{e}$ \\
\hline & 5 & 60.13 & 0.60 & 20.16 & 2.35 & 0.04 & 0.32 & 1.87 & 6.59 & 7.88 & 0.07 & 96.41 & $\mathrm{e}$ \\
\hline & 9 & 59.43 & 0.37 & 21.23 & 1.92 & 0.21 & 0.15 & 1.60 & 8.46 & 6.56 & 0.06 & 97.78 & $\bar{a}$ \\
\hline & 13 & 60.28 & 0.57 & 20.05 & 2.50 & 0.21 & 0.32 & 1.75 & 7.02 & 7.23 & 0.07 & 96.86 & $\mathrm{a}$ \\
\hline & 17 & 59.27 & 0.74 & 20.01 & 2.90 & 0.17 & 0.44 & 2.26 & 6.88 & 7.23 & 0.10 & 98.78 & $a$ \\
\hline & 30 & 60.13 & 0.50 & 20.26 & 2.23 & 0.10 & 0.31 & 1.83 & 6.64 & 7.94 & 0.08 & 98.14 & $\mathrm{e}$ \\
\hline & 34 & 60.21 & 0.48 & \begin{tabular}{|l|}
20.37 \\
\end{tabular} & 2.27 & 0.15 & 0.29 & 1.82 & 6.74 & 7.59 & 0.08 & 98.21 & $a$ \\
\hline & 38 & 60.18 & 0.61 & 20.03 & 2.30 & 0.15 & 0.33 & 1.88 & 6.59 & 7.86 & 0.08 & 98.87 & $a$ \\
\hline & 42 & 60.69 & 0.42 & 20.59 & 2.12 & 0.14 & 0.20 & 1.20 & 7.35 & 7.25 & 0.04 & 99.02 & $\bar{a}$ \\
\hline & 46 & 63.95 & 0.62 & 18.02 & 2.42 & 0.08 & 0.31 & 1.49 & 5.64 & 7.37 & 0.11 & 98.64 & $a$ \\
\hline & 47 & 71.57 & 0.30 & 13.95 & 3.64 & 0.19 & 0.24 & 1.45 & 5.10 & 3.47 & 0.09 & 97.26 & $\bar{a}$ \\
\hline & 51 & \begin{tabular}{|l|l|}
71.45 \\
\end{tabular} & 0.27 & 13.78 & 3.95 & 0.14 & 0.22 & 1.34 & 5.27 & 3.52 & 0.06 & 98.85 & $a$ \\
\hline \multicolumn{14}{|c|}{\begin{tabular}{|l|l|} 
MFM T685: 10,619 varve yrs BP & \\
\end{tabular}} \\
\hline & 3 & 60.07 & 0.52 & 20.09 & 2.52 & 0.21 & 0.28 & 1.65 & 6.77 & 7.79 & 0.08 & 95.89 & C \\
\hline & 5 & 60.48 & 0.29 & 20.71 & 1.96 & 0.20 & 0.18 & 1.42 & 7.80 & 6.89 & 0.07 & 96.20 & $\mathrm{a}$ \\
\hline & 7 & 59.37 & 0.63 & 20.37 & 2.70 & 0.14 & 0.35 & 2.19 & 6.29 & 7.82 & 0.13 & 98.25 & $\bar{a}$ \\
\hline & 9 & 60.20 & 0.55 & 20.30 & 2.26 & 0.15 & 0.29 & 1.82 & 6.73 & 7.65 & 0.07 & 97.55 & $\mathrm{c}$ \\
\hline & 11 & 60.41 & 0.56 & 20.25 & 2.17 & 0.10 & 0.27 & 1.87 & 6.49 & 7.68 & 0.18 & 97.47 & $\mathrm{a}$ \\
\hline & 13 & 60.21 & 0.60 & 20.28 & 2.43 & 0.18 & 0.28 & 1.69 & 6.82 & 7.45 & 0.06 & 98.19 & $\mathrm{C}$ \\
\hline & 15 & 59.88 & 0.74 & 20.16 & 2.76 & 0.19 & 0.44 & 1.82 & 6.41 & 7.49 & 0.12 & 99.16 & $a$ \\
\hline & 17 & 61.13 & 0.71 & 19.60 & 2.80 & 0.30 & 0.35 & 1.87 & 6.21 & 6.96 & 0.08 & 97.45 & $a$ \\
\hline & 20 & 60.59 & 0.45 & 20.12 & 2.18 & 0.12 & 0.30 & 1.85 & 6.64 & 7.69 & 0.06 & 98.97 & $a$ \\
\hline & 21 & 71.63 & 0.29 & \begin{tabular}{|l|}
13.62 \\
\end{tabular} & 3.70 & 0.09 & 0.26 & 1.37 & 5.39 & 3.61 & 0.03 & 98.54 & $\bar{e}$ \\
\hline & 22 & 71.45 & 0.27 & 13.78 & 3.95 & 0.14 & 0.22 & 1.34 & 5.27 & 3.52 & 0.06 & 98.85 & $a$ \\
\hline & 23 & 75.70 & 0.27 & 13.10 & 1.66 & 0.06 & 0.16 & 0.23 & 2.53 & 6.15 & 0.13 & 95.85 & $a$ \\
\hline \multicolumn{14}{|c|}{\begin{tabular}{|l|l|} 
MFM_T573: 7,744 varve yrs BP & \\
\end{tabular}} \\
\hline & 1 & 60.40 & 0.56 & 19.81 & 2.41 & 0.17 & 0.31 & 1.95 & 6.58 & 7.72 & 0.09 & 97.57 & $\mathrm{~g}$ \\
\hline & 2 & 60.60 & 0.55 & 20.02 & 2.25 & 0.20 & 0.31 & 1.83 & 6.60 & 7.55 & 0.09 & 97.45 & $\mathrm{~g}$ \\
\hline & 5 & 60.18 & 0.47 & 20.45 & 2.11 & 0.17 & 0.24 & 1.86 & 6.73 & 7.69 & 0.10 & 99.33 & $a$ \\
\hline & 6 & 61.29 & 0.38 & 20.22 & 1.77 & 0.05 & 0.20 & 1.72 & 6.63 & 7.70 & 0.04 & 97.66 & $\mathrm{~g}$ \\
\hline & 7 & 61.11 & 0.39 & 20.52 & 2.02 & 0.20 & 0.21 & 1.67 & 6.21 & 7.60 & 0.07 & 98.90 & $f$ \\
\hline & 8 & 62.19 & 0.33 & 19.12 & 2.06 & 0.13 & 0.42 & 1.33 & 6.26 & 8.12 & 0.02 & 99.28 & $g$ \\
\hline & 9 & 71.81 & 0.30 & 13.56 & 3.76 & 0.20 & 0.23 & 1.36 & 5.09 & 3.64 & 0.06 & 96.52 & $g$ \\
\hline & 10 & 71.48 & 0.28 & 13.50 & 4.01 & 0.13 & 0.21 & 1.34 & 5.50 & 3.50 & 0.03 & 97.87 & $g$ \\
\hline & 11 & 69.00 & 0.69 & \begin{tabular}{|l|}
7.45 \\
\end{tabular} & 4.68 & 0.11 & 1.60 & 1.89 & 5.93 & 8.59 & 0.06 & 98.65 & $f$ \\
\hline & 12 & 72.21 & 0.46 & 7.29 & 3.38 & 0.09 & 1.78 & 2.71 & 5.39 & 6.62 & 0.08 & 98.48 & $\mathrm{~g}$ \\
\hline & 13 & 71.93 & 0.60 & 6.69 & 4.38 & 0.10 & 1.72 & 3.00 & 5.04 & 6.51 & 0.05 & 98.93 & $f$ \\
\hline & 15 & 75.25 & 0.11 & 6.86 & 3.00 & 0.05 & 1.17 & 2.17 & 4.56 & 6.81 & 0.02 & 98.94 & $g$ \\
\hline \multicolumn{14}{|c|}{ MFM T568: 7,633 varve yrs BP } \\
\hline & 1 & 71.76 & 0.30 & 13.96 & 3.69 & 0.13 & 0.21 & 1.37 & 4.89 & 3.63 & 0.06 & 98.49 & a \\
\hline \multicolumn{14}{|c|}{\begin{tabular}{l|l|l|} 
MFM T552: 7,314 varve yrs BP & \\
\end{tabular}} \\
\hline & 1 & 62.49 & 0.64 & 19.03 & 2.22 & 0.24 & 0.34 & 1.49 & 6.40 & 7.04 & 0.12 & 100.33 & a \\
\hline \multicolumn{14}{|c|}{\begin{tabular}{|l|l|l|} 
MFM T550: 7,279 varve yrs BP & \\
\end{tabular}} \\
\hline & 1 & 60.68 & 0.61 & 19.83 & 2.30 & 0.19 & 0.28 & 1.34 & 7.95 & 6.75 & 0.08 & 97.18 & $f$ \\
\hline & 2 & 75.26 & 0.49 & 13.70 & 1.33 & 0.11 & 0.36 & 0.46 & 3.59 & 4.70 & 0.02 & 95.67 & $f$ \\
\hline \multicolumn{14}{|c|}{\begin{tabular}{l|l|l} 
MFM T548: 7,245 varve yrs BP & \\
\end{tabular}} \\
\hline & 1 & 60.25 & 0.52 & 20.10 & 2.30 & 0.23 & 0.25 & 1.71 & 7.01 & 7.58 & 0.05 & 98.78 & $f$ \\
\hline & 2 & 63.61 & 0.27 & 17.96 & 3.66 & 0.27 & 0.19 & 0.70 & 7.98 & 5.31 & 0.04 & 98.33 & $f$ \\
\hline \multicolumn{14}{|c|}{\begin{tabular}{|l|l|l|l|} 
MFM_T334: 3,382 varve yrs BP & \\
\end{tabular}} \\
\hline & 1 & \begin{tabular}{|l|}
62.49 \\
\end{tabular} & 0.64 & \begin{tabular}{|l|}
17.999 \\
\end{tabular} & 3.92 & 0.21 & 0.58 & 1.67 & 7.30 & 5.00 & 0.20 & 96.73 & $f$ \\
\hline & 2 & 63.88 & 0.41 & \begin{tabular}{|l|}
17.16 \\
\end{tabular} & 4.28 & 0.24 & 0.28 & 0.86 & 7.95 & 4.87 & 0.08 & 97.18 & $f$ \\
\hline & 3 & 64.59 & 0.21 & 16.62 & 4.38 & 0.22 & 0.12 & 0.60 & 8.33 & 4.90 & \begin{tabular}{|l|}
0.03 \\
\end{tabular} & 98.00 & $f$ \\
\hline \multicolumn{14}{|c|}{\begin{tabular}{|l|l|l|} 
MFM T238: 3,230 varve yrs BP & \\
\end{tabular}} \\
\hline & 1 & \begin{tabular}{|l|}
63.87 \\
\end{tabular} & 0.08 & 19.03 & 0.96 & 0.09 & 0.41 & 1.78 & 6.39 & 7.38 & 0.01 & 100.36 & $a$ \\
\hline & 2 & 67.85 & 0.59 & \begin{tabular}{|l}
14.73 \\
\end{tabular} & 4.68 & 0.17 & 1.88 & 0.25 & 2.80 & 6.86 & 0.18 & 99.85 & $a$ \\
\hline
\end{tabular}


587

588

589

590

591

592

Table 2:

Single-shard trace element compositions (ppm) of tephra layers within the Meerfelder Maar record, measured by laser ablation inductively coupled plasma mass spectrometry (section 2.3). Secondary standard data, which provide a measure of precision and accuracy, are presented within Supplementary Information. " $<$ LOD" indicates the element concentration was below the limits of detection for that analyses.

\begin{tabular}{|c|c|c|c|c|c|c|c|c|c|c|c|c|c|c|c|c|c|c|c|c|c|c|}
\hline & EPMA \# & $\mathbf{R b}$ & $\mathrm{Sr}$ & Y & $\mathrm{zr}$ & Nb & Ba & La & Ce & $\operatorname{Pr}$ & Nd & $\mathrm{Sm}$ & Eu & Gd & Dy & Er & $\mathrm{Yb}$ & Lu & Ta & Th & $\mathbf{U}$ & Std fild \\
\hline \multicolumn{23}{|c|}{ MFM_T1072: 14,230 varve yrs BP } \\
\hline & 7 & 335 & 863 & 30 & 303 & 47 & 1482 & 74 & 137 & 16 & 57 & 11.6 & 2.2 & $\angle L O D$ & 5.7 & 2.3 & $\angle L O D$ & $<L O D$ & 2.5 & 25.3 & 8.6 & a \\
\hline & 4 & 318 & 903 & 29 & 295 & 44 & 1597 & 71 & 136 & 13 & 59 & 10.4 & 2.3 & 6.3 & 5.6 & 2.9 & $\angle L O D$ & 0.4 & 2.1 & 26.2 & 7.5 & $\mathrm{~b}$ \\
\hline & 8 & 308 & 926 & 30 & 292 & 44 & 1643 & 72 & 148 & 13 & \begin{tabular}{|c|}
62 \\
\end{tabular} & 10.8 & 2.2 & 4.8 & 4.6 & 2.9 & 2.7 & $\angle L O D$ & 2.0 & 26.2 & 7.9 & $\mathrm{~b}$ \\
\hline & 11 & 321 & 466 & 31 & \begin{tabular}{l|l}
324 \\
\end{tabular} & 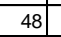 & 782 & 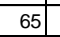 & 125 & 12 & 52 & 9.8 & 2.0 & 5.7 & 4.9 & 2.9 & 3.4 & $\angle L O D$ & 2.3 & 26.9 & 8.0 & $\mathrm{~b}$ \\
\hline & 17 & 303 & 227 & 217 & 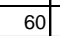 & 6 & 541 & 54 & 110 & 12 & 48 & 11.9 & 2.2 & 23.2 & 39.0 & 14.7 & 5.2 & \begin{tabular}{|c|}
0.4 \\
\end{tabular} & 0.5 & 15.5 & 11.5 & $\mathrm{a}$ \\
\hline & 18 & 63 & 158 & 40 & 21 & 13 & 113 & 48 & 98 & 11 & \begin{tabular}{|c|}
46 \\
\end{tabular} & 10.8 & 1.4 & 7.9 & 7.6 & 4.0 & 3.8 & 0.6 & 0.6 & 9.4 & 2.9 & $\mathrm{a}$ \\
\hline \multicolumn{23}{|c|}{\begin{tabular}{|l|l|l|} 
MFM_T876: 12,880 varve yrs BP & \\
\end{tabular}} \\
\hline & 4 & 198 & 224 & 16 & 452 & 146 & 265 & 104 & 158 & 13 & 37 & $\angle L O D$ & $\angle L O D$ & $\angle L O D$ & 2.3 & 1.7 & 2.2 & $\angle L O D$ & 6.3 & 15.7 & 4.1 & $\mathrm{~b}$ \\
\hline & 7 & 183 & 330 & 15 & 466 & 132 & 392 & \begin{tabular}{l|l}
93 & 0
\end{tabular} & 144 & 12 & 35 & 4.0 & 1.0 & \begin{tabular}{rl|}
2.4 \\
\end{tabular} & 2.4 & 1.6 & 2.2 & \begin{tabular}{|c|}
0.3 \\
\end{tabular} & 5.2 & 15.0 & 3.9 & $\mathrm{~b}$ \\
\hline \multicolumn{23}{|c|}{\begin{tabular}{|l|l|l|} 
MFM_T801: 12,140 varve yrs BP & \\
\end{tabular}} \\
\hline & 1 & \begin{tabular}{|l|}
28 \\
\end{tabular} & 396 & 42 & 355 & 50 & 278 & 36 & 83 & 11 & \begin{tabular}{|l|}
46 \\
\end{tabular} & 10.6 & 3.2 & 10.8 & 8.9 & 4.3 & 3.7 & $\angle L O D$ & 3.0 & 3.8 & 1.2 & c \\
\hline & 2 & 29 & 397 & 46 & 370 & 53 & 296 & 39 & 89 & 11 & \begin{tabular}{|l|}
49 \\
\end{tabular} & 11.1 & 3.3 & 10.3 & 9.5 & 4.7 & 3.8 & $\angle L O D$ & 3.4 & 4.2 & $\angle$ LOD & c \\
\hline & 4 & 32 & 395 & 46 & \begin{tabular}{|l|}
400 \\
\end{tabular} & 56 & 333 & 43 & 95 & \begin{tabular}{|l|}
11 \\
\end{tabular} & \begin{tabular}{|l|}
52 \\
\end{tabular} & 10.9 & 3.3 & $\begin{array}{l}10.6 \\
\end{array}$ & 10.0 & 5.4 & 4.3 & $\angle L O D$ & 3.4 & 4.4 & $\angle L O D$ & $\mathrm{c}$ \\
\hline & 5 & 32 & 363 & 46 & \begin{tabular}{|l|}
393 \\
\end{tabular} & 54 & 301 & 40 & 92 & 11 . & \begin{tabular}{|l|}
47 \\
\end{tabular} & \begin{tabular}{ll|}
10.6 \\
\end{tabular} & 2.9 & 11.2 & $\begin{array}{l}9.1 \\
\end{array}$ & 4.5 & 3.7 & $\angle L O D$ & 3.3 & 4.2 & $\angle L O D$ & c \\
\hline & 7 & 31 & 391 & 44 & \begin{tabular}{|l|}
364 \\
\end{tabular} & 52 & 289 & 38 & \begin{tabular}{l|l|}
88 \\
\end{tabular} & \begin{tabular}{|l|}
11 \\
\end{tabular} & \begin{tabular}{|l|}
48 \\
\end{tabular} & 11.8 & 3.1 & 11.3 & 8.9 & 4.4 & 4.1 & $\angle L O D$ & 3.1 & 4.1 & $\angle L O D$ & $\mathrm{c}$ \\
\hline & 9 & 35 & 388 & 48 & \begin{tabular}{|l|}
424 \\
\end{tabular} & 58 & 320 & 43 & \begin{tabular}{l|l}
96 \\
\end{tabular} & \begin{tabular}{|l|}
12 \\
\end{tabular} & \begin{tabular}{|l|}
53 \\
\end{tabular} & 12.1 & 3.2 & 11.0 & \begin{tabular}{l|l|}
9.3 \\
\end{tabular} & 5.0 & 4.1 & $\angle L O D$ & 3.6 & 4.7 & \begin{tabular}{|r|}
1.5 \\
\end{tabular} & $\mathrm{c}$ \\
\hline & 10 & 38 & 386 & 51 & \begin{tabular}{|l|}
448 \\
\end{tabular} & 63 & 358 & 45 & 105 & 12 | & \begin{tabular}{|l|}
52 \\
\end{tabular} & 13.2 & 3.3 & 10.7 & 10.3 & 5.5 & 4.5 & $\angle L O D$ & 3.8 & 5.1 & 1.7 & c \\
\hline & 15 & 36 & 414 & 55 & \begin{tabular}{|l|}
454 \\
\end{tabular} & 63 & 385 & \begin{tabular}{|l|l|}
49 & \\
\end{tabular} & \begin{tabular}{ll|}
110 \\
\end{tabular} & \begin{tabular}{|l|}
13 \\
\end{tabular} & \begin{tabular}{|l|}
62 \\
\end{tabular} & 14.9 & 3.7 & 12.3 & 11.7 & 5.5 & 4.4 & $\angle L O D$ & 3.5 & 5.1 & $\mid<\angle O D$ & $\mathrm{c}$ \\
\hline & 18 & 29 & 378 & 43 & 364 & 50 & 318 & \begin{tabular}{l|l}
38 & \\
\end{tabular} & 86 & 11 & \begin{tabular}{|l|}
46 \\
\end{tabular} & 11.4 & 3.2 & 10.5 & 8.8 & 4.4 & 3.4 & $\angle L O D$ & 3.4 & 4.2 & \begin{tabular}{|l|}
1.4 \\
\end{tabular} & c \\
\hline & 23 & 46 & 328 & 55 & \begin{tabular}{|l|}
514 \\
\end{tabular} & 73 & 396 & \begin{tabular}{l|l|}
52 & \\
\end{tabular} & $\begin{array}{l}117 \\
\end{array}$ & \begin{tabular}{|l|}
14 \\
\end{tabular} & \begin{tabular}{|l|}
60 \\
\end{tabular} & $\begin{array}{l}12.7 \\
\end{array}$ & 3.3 & 12.3 & 11.8 & 5.9 & 4.9 & $\angle L O D$ & 4.3 & $\begin{array}{ll}6.0 \\
\end{array}$ & 2.1 & $\mathrm{c}$ \\
\hline & 25 & \begin{tabular}{l|l}
41 \\
\end{tabular} & 451 & 61 & \begin{tabular}{|l|}
507 \\
\end{tabular} & 70 & \begin{tabular}{l|l}
413 \\
\end{tabular} & \begin{tabular}{|l|l|}
57 \\
\end{tabular} & \begin{tabular}{l|l}
127 \\
\end{tabular} & \begin{tabular}{|l|}
16 \\
\end{tabular} & \begin{tabular}{|l|}
65 \\
\end{tabular} & $\begin{array}{l}17.6 \\
\end{array}$ & 4.8 & 13.7 & $\begin{array}{ll}12.8 \\
\end{array}$ & 6.4 & 5.0 & $\angle L O D$ & 4.0 & 5.8 & 1.7 & c \\
\hline & 28 & 44 & 410 & 64 & \begin{tabular}{|l|}
562 \\
\end{tabular} & 77 & 460 & 64 & \begin{tabular}{ll|}
133 \\
\end{tabular} & \begin{tabular}{|l|}
17 \\
\end{tabular} & \begin{tabular}{|l|}
73 \\
\end{tabular} & 16.3 & 4.6 & $\begin{array}{l}16.1 \\
\end{array}$ & 13.2 & 6.7 & 5.6 & $\angle L O D$ & 4.3 & 6.4 & 2.0 & $\mathrm{c}$ \\
\hline & 34 & \begin{tabular}{|l|l|}
86 & \\
\end{tabular} & 123 & 84 & \begin{tabular}{|l|}
922 \\
\end{tabular} & 126 & $\begin{array}{ll}673 \\
\end{array}$ & \begin{tabular}{|l|l|}
88 \\
\end{tabular} & 191 & \begin{tabular}{|l|}
22 \\
\end{tabular} & \begin{tabular}{|l|}
84 \\
\end{tabular} & 19.5 & 3.5 & $\begin{array}{l}16.3 \\
\end{array}$ & 15.8 & 8.7 & 8.2 & $\angle L O D$ & 7.0 & \begin{tabular}{ll|}
11.6 \\
\end{tabular} & 3.4 & $\mathrm{c}$ \\
\hline & 35 & 78 & 118 & 79 & \begin{tabular}{|l|}
870 \\
\end{tabular} & 120 & 655 & 88 & 186 & \begin{tabular}{|l|}
21 \\
\end{tabular} & \begin{tabular}{|l|}
91 \\
\end{tabular} & 19.5 & 3.7 & 16.2 & 16.0 & 8.7 & 7.5 & $\angle L O D$ & 7.3 & $\begin{array}{l}11.6 \\
\end{array}$ & 3.6 & c \\
\hline & 36 & \begin{tabular}{l|l|}
87 \\
\end{tabular} & $\begin{array}{l}127 \\
\end{array}$ & 88 & \begin{tabular}{|l|}
948 \\
\end{tabular} & 132 & \begin{tabular}{l|l}
696 \\
\end{tabular} & \begin{tabular}{|l|l|}
93 & \\
\end{tabular} & 201 & \begin{tabular}{|l|}
24 \\
\end{tabular} & \begin{tabular}{|l|}
92 \\
\end{tabular} & 20.1 & 3.7 & 18.1 & 17.4 & 9.3 & 8.7 & $\angle L O D$ & 7.6 & 12.6 & 3.8 & $\mathrm{c}$ \\
\hline \multicolumn{23}{|c|}{ MFM_T687:10,648 varve yrs BP } \\
\hline & 9 & 216 & 26 & 14 & \begin{tabular}{|c|}
606 \\
\end{tabular} & 152 & 31 & 109 & 151 & 10 & 25 & $\angle \mathrm{LOD}$ & $\angle \mathrm{LOD}$ & $\angle L O D$ & 1.8 & 1.7 & 2.2 & 0.4 & 4.8 & 21.3 & 5.5 & $\mathrm{a}$ \\
\hline & 16 & 181 & 340 & 15 & 368 & 117 & 538 & 81 & 131 & 10 & 32 & $\angle L O D$ & $\angle L O D$ & $\angle L O D$ & $\angle L O D$ & $\angle L O D$ & $\angle L O D$ & $\angle L O D$ & 4.8 & 11.8 & 3.4 & $\mathrm{a}$ \\
\hline & 25 & 200 & 366 & 13 & 411 & 126 & 595 & 79 & 123 & 9 & 27 & $\angle L O D$ & $\angle L O D$ & $\angle L O D$ & 2.0 & \begin{tabular}{|l|}
1.2 \\
\end{tabular} & \begin{tabular}{|l|}
1.6 \\
\end{tabular} & \begin{tabular}{|l|}
0.3 \\
\end{tabular} & 4.2 & 13.1 & 3.5 & $\mathrm{a}$ \\
\hline & 32 & 267 & 98 & 16 & 981 & 249 & 49 & 111 & \begin{tabular}{|c|}
167 \\
\end{tabular} & 12 & 30 & $\angle L O D$ & $\angle L O D$ & 3.3 & 2.2 & 1.7 & 2.9 & 0.5 & 5.4 & 34.1 & 8.0 & $\mathrm{a}$ \\
\hline & 34 & 199 & 359 & 15 & 455 & 137 & 527 & 96 & 143 & $11 \mid$ & 30 . & $\angle L O D$ & 1.0 & $\angle L O D$ & 2.1 & $\angle L O D$ & \begin{tabular}{|l|}
$\angle L O D$ \\
\end{tabular} & \begin{tabular}{|l|}
$\angle O O D$ \\
\end{tabular} & 5.3 & \begin{tabular}{ll|}
14.2 \\
\end{tabular} & 3.8 & $a$ \\
\hline & 38 & \begin{tabular}{l|l}
188 \\
\end{tabular} & 374 & 18 & \begin{tabular}{|l|}
438 \\
\end{tabular} & 144 & \begin{tabular}{l|l}
525 \\
\end{tabular} & \begin{tabular}{ll|}
104 \\
\end{tabular} & \begin{tabular}{l|l|}
159 \\
\end{tabular} & \begin{tabular}{|l|}
13 \\
\end{tabular} & 35 | & $\angle L O D$ & $<\angle O D$ & $\angle L O D$ & 2.9 & \begin{tabular}{|l|}
1.8 \\
\end{tabular} & \begin{tabular}{|r|}
2.3 \\
\end{tabular} & \begin{tabular}{|l|}
0.4 \\
\end{tabular} & 5.9 & 15.2 & 3.6 & $a$ \\
\hline & 39 & 172 & 454 & 16 & 380 & 129 & 697 & 91 & \begin{tabular}{|l|l|}
143 \\
\end{tabular} & 11 & 34 & $<\angle O D$ & 0.9 & $\angle L O D$ & 2.3 & 1.6 & $\angle \angle O D$ & $<\angle O D$ & 5.0 & 13.3 & 3.2 & $\mathrm{a}$ \\
\hline & 44 & 224 & \begin{tabular}{l|l|}
23 \\
\end{tabular} & 12 & \begin{tabular}{|l|}
537 \\
\end{tabular} & $\begin{array}{l}126 \\
\end{array}$ & 19 & \begin{tabular}{|l|l|}
97 \\
\end{tabular} & 131 & 9 & \begin{tabular}{|l|}
22 \\
\end{tabular} & $\angle L O D$ & $\angle \angle O D$ & $\angle L O D$ & 1.7 & 1.4 & 1.8 & $\angle L O D$ & 4.2 & \begin{tabular}{|l|}
19.2 \\
\end{tabular} & 5.3 & $a$ \\
\hline & 45 & 189 & 97 & 22 & \begin{tabular}{|l|}
309 \\
\end{tabular} & $\begin{array}{l}147 \\
\end{array}$ & 119 & \begin{tabular}{ll|}
128 \\
\end{tabular} & $\begin{array}{ll}218 \\
\end{array}$ & \begin{tabular}{|l|}
18 \\
\end{tabular} & \begin{tabular}{|l|}
55 \\
\end{tabular} & \begin{tabular}{|r|}
6.6 \\
\end{tabular} & \begin{tabular}{|l|}
1.0 \\
\end{tabular} & \begin{tabular}{|r|}
4.6 \\
\end{tabular} & 3.7 & 2.2 & 2.4 & \begin{tabular}{|l|}
0.3 \\
\end{tabular} & 7.2 & \begin{tabular}{|l|}
9.7 \\
\end{tabular} & 2.2 & $\mathrm{a}$ \\
\hline & 46 & 207 & 252 & 26 & \begin{tabular}{|l|}
386 \\
\end{tabular} & 110 & 227 & \begin{tabular}{|l|l|}
95 & \\
\end{tabular} & $\begin{array}{ll}155 \\
\end{array}$ & \begin{tabular}{|l|}
13 \\
\end{tabular} & \begin{tabular}{|l|}
43 \\
\end{tabular} & 6.4 . & $\angle \angle O D$ & $\angle L O D$ & 4.4 & 2.5 & \begin{tabular}{l|l}
2.8 \\
\end{tabular} & 0.5 & 4.7 & 18.8 & 3.9 & $a$ \\
\hline & 49 & \begin{tabular}{l|l}
90 \\
\end{tabular} & 128 & 89 & \begin{tabular}{|l|}
956 \\
\end{tabular} & 132 & \begin{tabular}{l|l|}
716 \\
\end{tabular} & \begin{tabular}{l|l|}
96 \\
\end{tabular} & \begin{tabular}{|l|}
207 \\
\end{tabular} & 22 & \begin{tabular}{|l|}
93 \\
\end{tabular} & 20.3 & \begin{tabular}{|l|}
4.0 \\
\end{tabular} & \begin{tabular}{|l|}
18.6 \\
\end{tabular} & 17.3 & 9.1 & \begin{tabular}{ll|}
9.0 \\
\end{tabular} & 1.2 & 7.4 & 12.4 & 4.0 & $\mathrm{~b}$ \\
\hline & 50 & 89 & 122 & 87 & 873 & 126 & 660 & 86 & 193 & $21 \mid$ & \begin{tabular}{|l|}
83 \\
\end{tabular} & 19.1 & 3.7 & 15.3 & 15.7 & 8.3 & \begin{tabular}{l|l|}
7.8 \\
\end{tabular} & 1.1 & 6.9 & \begin{tabular}{|l|}
10.6 \\
\end{tabular} & 3.2 & $b$ \\
\hline & 51 & 83 & 141 & 89 & \begin{tabular}{|l|}
923 \\
\end{tabular} & $\begin{array}{ll}126 \\
\end{array}$ & $\begin{array}{ll}725 \\
\end{array}$ & \begin{tabular}{l|l}
93 \\
\end{tabular} & 196 & \begin{tabular}{|l|}
23 \\
\end{tabular} & \begin{tabular}{|l|}
96 \\
\end{tabular} & 20.5 & $\begin{array}{l}4.2 \\
\end{array}$ & 18.2 & $\begin{array}{l}16.3 \\
\end{array}$ & 8.9 & 8.1 & $\begin{array}{ll}1.2 \\
\end{array}$ & 7.6 & \begin{tabular}{ll|}
12.2 \\
\end{tabular} & 3.9 & $\mathrm{a}$ \\
\hline & EPMA\# & $\begin{array}{l}\mathbf{R b} \\
\end{array}$ & Sr & $\begin{array}{ll}y \\
\end{array}$ & \begin{tabular}{|l|l}
$\mathrm{Zr}$ \\
\end{tabular} & $\begin{array}{l}\mathrm{Nb} \\
\end{array}$ & \begin{tabular}{ll|}
$\mathrm{Ba}$ & \\
\end{tabular} & \begin{tabular}{l|l} 
La \\
\end{tabular} & $\begin{array}{ll}\mathrm{Ce} & \\
\end{array}$ & $\mathrm{Pr}$ & $\mathrm{Nd}$ & Sm & Eu & $\begin{array}{ll}\text { Gd } \\
\end{array}$ & Dy & Er & \begin{tabular}{l|l|}
$\mathbf{Y b}$ \\
\end{tabular} & Lu & \begin{tabular}{l|l}
$\mathrm{Ta}$ \\
\end{tabular} & Th & \begin{tabular}{l|l}
$U$ \\
\end{tabular} & Std fild \\
\hline \multicolumn{23}{|c|}{ MFM_T685: 10,619 varve yrs BP } \\
\hline & 6 & 195 & 438 & 15 & 411 & 132 & 798 & 88 & 140 & 11 & 34 & 4.7 & 1.2 & $\angle L O D$ & 2.6 & 1.5 & 2.0 & 0.3 & 5.3 & 13.8 & 3.7 & d \\
\hline & 10 & 197 & 394 & 14 & 374 & 124 & 664 & 89 & \begin{tabular}{l|l}
137 \\
\end{tabular} & 11 & 31 & 4.0 & 1.0 & $\angle L O D$ & 2.2 & 1.6 & 1.8 & 0.3 & 4.7 & 13.3 & 3.5 & $\mathrm{~d}$ \\
\hline & 15 & 218 & 280 & 20 & 398 & 154 & 426 & 110 & 176 & 15 & 45 & 5.1 & 1.3 & $\angle L O D$ & 3.1 & 2.2 & 2.3 & 0.4 & 7.3 & 13.5 & 2.8 & d \\
\hline & 16 & 212 & 375 & 15 & 437 & 143 & 584 & 100 & 148 & 12 & 33 & 4.0 & 1.0 & $\angle L O D$ & 2.4 & 1.7 & 2.0 & 0.3 & 5.8 & 16.3 & 4.1 & $\mathrm{~d}$ \\
\hline & 17 & 242 & 118 & 32 & \begin{tabular}{|l|l|}
563 & -2 \\
\end{tabular} & 235 & 168 & \begin{tabular}{l|l}
145 \\
\end{tabular} & 254 & $22 \mid$ & \begin{tabular}{|c|}
67 \\
\end{tabular} & 7.8 & 1.3 & 5.8 & 5.3 & 3.5 & 4.1 & 0.6 & 10.4 & \begin{tabular}{|c|}
19.3 \\
\end{tabular} & 4.7 & $\mathrm{~d}$ \\
\hline & 20 & 192 & 377 & 18 & 348 & 107 & 587 & \begin{tabular}{l|l}
88 & $r$ \\
\end{tabular} & 140 & 11 & 34 & 5.0 & 1.0 & $\angle L O D$ & 2.6 & 1.9 & 2.3 & 0.3 & 4.3 & \begin{tabular}{|c|}
14.4 \\
\end{tabular} & 3.4 & $\mathrm{~d}$ \\
\hline \multicolumn{23}{|c|}{\begin{tabular}{l|l|l|} 
MFM_T573: 7,744 varve yrs BP & \\
\end{tabular}} \\
\hline & 2 & 209 & 400 & 15 & 437 & 134 & 653 & 97 & 146 & 11 & 32 & $\angle L O D$ & 1.1 & $\angle L O D$ & 2.3 & 1.5 & 2.0 & $\angle L O D$ & 5.3 & 16.0 & 3.8 & $\mathrm{~b}$ \\
\hline & 3 & 194 & 197 & 12 & \begin{tabular}{|l|}
493 \\
\end{tabular} & 136 & 166 & 102 & 140 & $10 \mid$ & 25 . & $\angle L O D$ & $\angle L O D$ & $\angle L O D$ & 1.8 & 1.4 & 2.0 & $\angle L O D$ & 4.6 & \begin{tabular}{|c|}
16.9 \\
\end{tabular} & 4.5 & $\mathrm{~b}$ \\
\hline & 4 & 190 & 200 & 13 & 498 & 140 & 178 & 102 & 145 & 10 & 24 & $\angle L O D$ & 0.6 & $\angle L O D$ & 1.8 & 1.4 & 2.2 & 0.3 & 4.8 & 17.6 & 4.6 & d \\
\hline & 6 & 218 & 310 & 11 & 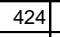 & 118 & 542 & \begin{tabular}{|c|}
86 \\
\end{tabular} & 124 & 9 & 21. & $\angle L O D$ & 0.7 & $\angle L O D$ & \begin{tabular}{l|l}
1.6 \\
\end{tabular} & 1.3 & 1.7 & 0.3 & 4.1 & 14.6 & 4.1 & $\mathrm{~b}$ \\
\hline & 11 & \begin{tabular}{|c|}
89 \\
\end{tabular} & 121 & 86 & \begin{tabular}{|l|}
876 \\
\end{tabular} & 130 & 654 & 86 & \begin{tabular}{l|l}
192 \\
\end{tabular} & \begin{tabular}{|l|}
22 \\
\end{tabular} & 85 & 18.9 & 3.5 & \begin{tabular}{|l|}
16.1 \\
\end{tabular} & 15.7 & 8.2 & 8.7 & 1.0 & 6.5 & \begin{tabular}{|c|}
11.7 \\
\end{tabular} & 3.3 & $\mathrm{~b}$ \\
\hline & 13 & 216 & 325 & 14 & 30 & 11 & 349 & 22 & 43 & 5 & 18 & 3.9 & 1.0 & \begin{tabular}{r|r}
2.7 \\
\end{tabular} & 2.6 & 1.4 & 1.0 & $\angle L O D$ & 0.5 & 3.9 & 1.0 & d \\
\hline \multicolumn{23}{|c|}{ FFM_T334: 3,382 varve yrs BP } \\
\hline & 1 & $94 \mid$ & 130 & 30 & 448 & 87 & 974 & \begin{tabular}{l|l}
65 & \\
\end{tabular} & 123 & 13 & \begin{tabular}{|c|}
47 \\
\end{tabular} & 8.6 & 2.4 & 6.7 & 5.5 & 3.3 & 3.2 & 0.5 & 4.8 & 8.2 & 2.3 & a \\
\hline & 2 & 134 & 50 & \begin{tabular}{|l|l|}
49 \\
\end{tabular} & $\mid 881$ & 158 & 279 & \begin{tabular}{|l|l}
99 \\
\end{tabular} & 185 & \begin{tabular}{|l|}
19 \\
\end{tabular} & \begin{tabular}{|l|}
59 \\
\end{tabular} & 11.1 & 1.2 & \begin{tabular}{|l|}
8.3 \\
\end{tabular} & \begin{tabular}{|c|}
8.6 \\
\end{tabular} & 5.0 & \begin{tabular}{|c|}
5.9 \\
\end{tabular} & \begin{tabular}{|c|}
0.8 \\
\end{tabular} & \begin{tabular}{|l|}
8.7 \\
\end{tabular} & 13.3 & \begin{tabular}{|l|}
4.8 \\
\end{tabular} & $a$ \\
\hline
\end{tabular}


595

596

597

598

599

600

601

602

603

604

605

606

607

608

Table 3:

Mean varve ages of the main Lateglacial tephra layers and the UMT and their age relationships to the major biostratigraphic units (pollen zones) as defined by Litt and Stebich (1999) in the MFM sediment record. *Varve ages from the re-counted interval of the MFM2015 varve chronology. For comparison with the GRIP/NGRIP ice cores the Meiendorf pollen zone has been tentatively correlated with $\mathrm{Gl}-1 \mathrm{e}$ and the Oldest Dryas with $\mathrm{GI}-1 \mathrm{~d}$, respectively (Brauer et al., 2000b).

\begin{tabular}{|c|c|c|l|}
\hline \multicolumn{1}{|c|}{ Tephra layer } & Boundary & Varve ages BP & \multicolumn{1}{c|}{ Local biostratigraphic position } \\
\hline MFM_T711 / Ulmener Maar tephra, West Efel, German & 11,000 & 590 years after transition to Holocene \\
\hline \multicolumn{2}{|l|}{ Younger Dryas / Holocen } & 11,590 & \\
\hline MFM_T801 / Vedde Ash, Katla, lceland & 12,140 & $\begin{array}{l}539 \text { years after transition to YD; } \\
550 \text { years before transition to } \\
\text { Holocene }\end{array}$ \\
\hline \multicolumn{2}{|l|}{ Allerød / Younger Dryas } & 12,679 & $\begin{array}{l}470 \text { years after start of Allerød; } \\
200 \text { years before transition to YD; }\end{array}$ \\
\hline MFM_T876 / Laacher See Tephra, East Eifel, Germany & 12,880 & $\begin{array}{l}350 \text { - 400 years after start of } \\
\text { 235 years } \\
\text { beiendorf } \\
\text { before transition to Oldest Dryas }\end{array}$ \\
\hline MFM_T1072 / Neapolitan Yellow Tuff, Campi Flegrei, It & Meiendorf / Oldest Dryas & $13,995^{*}$ & $14,230^{*}$ \\
\hline & Pleniglacial / Meiendorf & ca. 14,600* & $\begin{array}{l}\text { duration extrapolated (no varve } \\
\text { counting) }\end{array}$ \\
\hline
\end{tabular}

Figure 1:

Location map showing Meerfelder Maar, in the West Eifel, volcanic centres and other sites mentioned in the text. Insert shows topography of the Meerfelder crater and bathymetry of the lake basin, with the MFM-09 and MFM- 6 core locations.

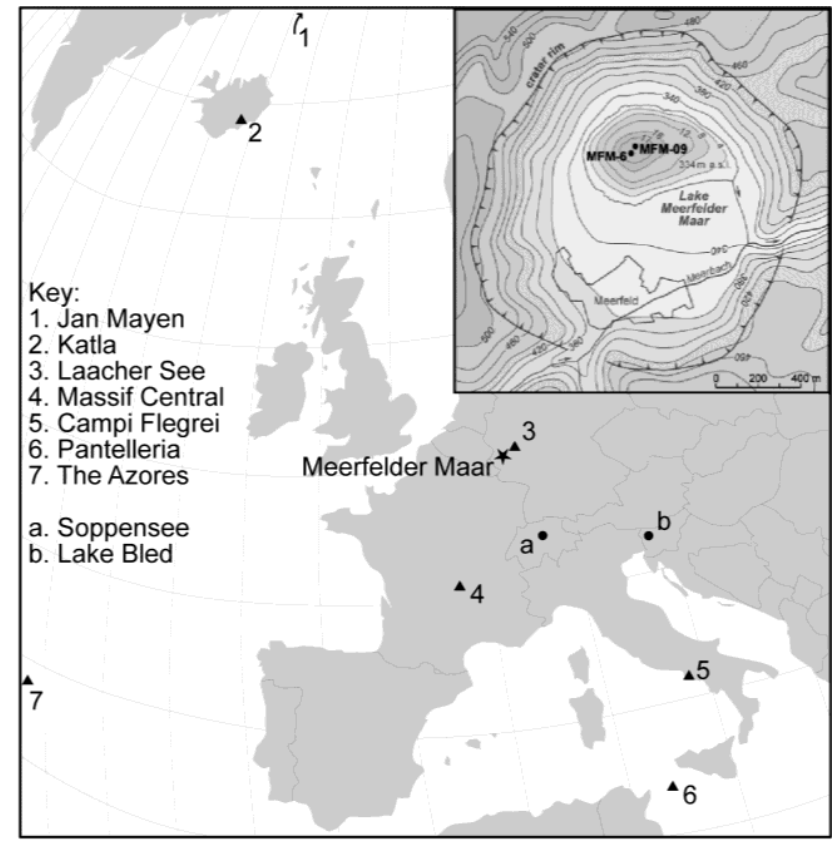


612 Figure 2:

613 a) Plot of tephra glass shard counts (shards per gram dry sediment) against MFM09 614 composite depth (left hand axis) in the Meerfelder Maar composite profile. Tephra layers 615 sample codes are based upon their first occurrence depth below lake floor (cm). b) the 616 MFM2015 age-depth profile for MFM09 is shown with the LST and UMT marker tephra 617 layers indicated alongside (c) the varve counted sections from the previous MFM cores that 618 comprise the final MFM2015 chronology (section 3.1).

619

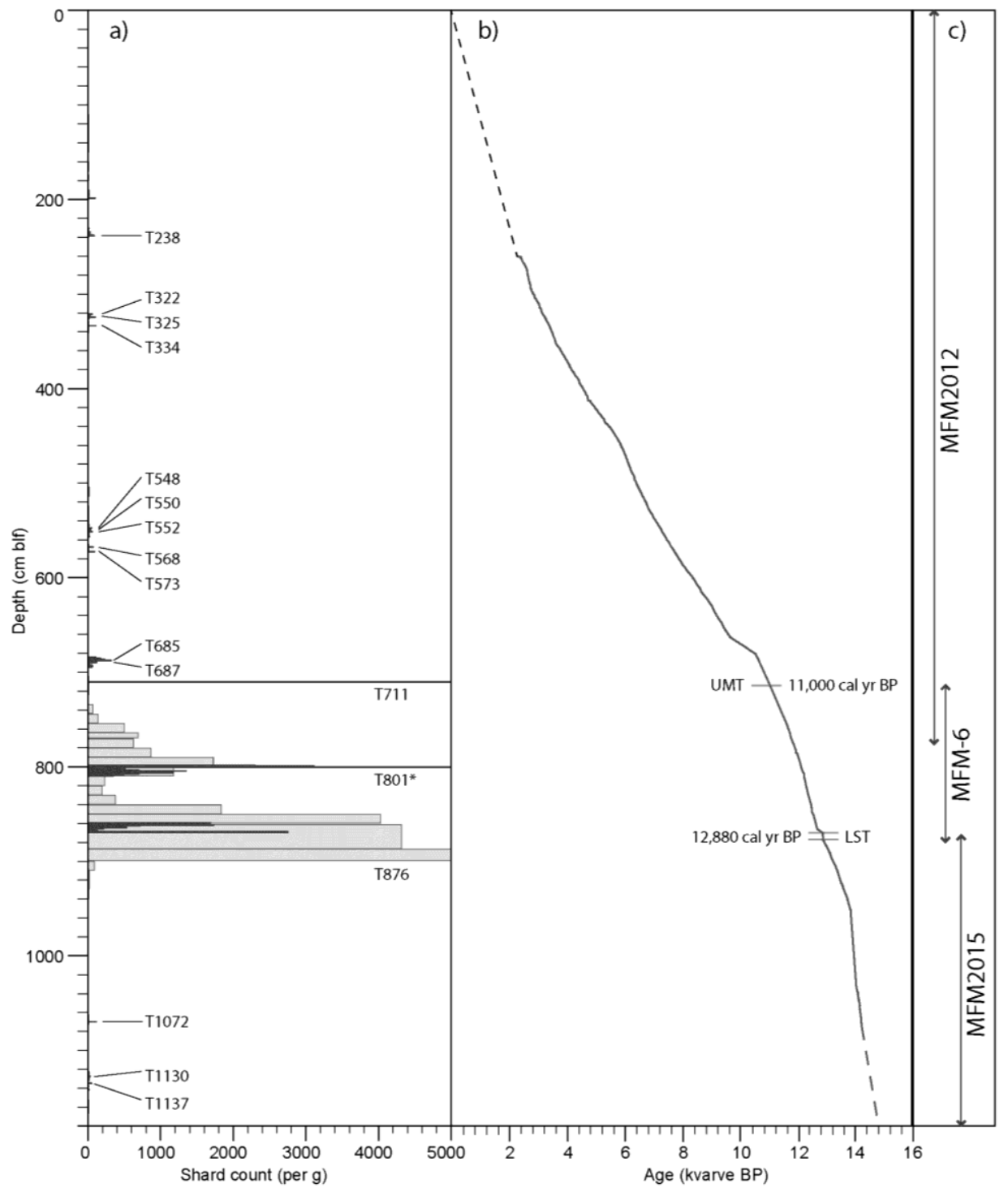




\section{Figure 3:}

622 Core photograph of the section below the Laacher See Tephra (LST) for which the published MFM-6 chronology (red line; Brauer et al., 1999) has been slightly revised by varve counting in new cores (MFM09), labelled as updated MFM2015 chronology (blue line). (a) Core photo and lithological description. (b) Age-depth model for the MFM-6 (in red) and MFM2015 (in blue) chronologies. The upper slumped section (*,8 cm thick) is present in both composite profiles and 110 varves have been interpolated (Brauer et al., 1999). The lower slumped section (**, $80 \mathrm{~cm}$ thick) is well laminated in the profile MFM- 6 and 200 varves have been adopted from the MFM- 6 chronology. Both records are precisely correlated using four macroscopically visible (ML28 - ML31) and microscopic (not shown) marker layers. The position of the non-visible Neapolitan Yellow Tuff (NYT) is indicated with an arrow in the lower part.

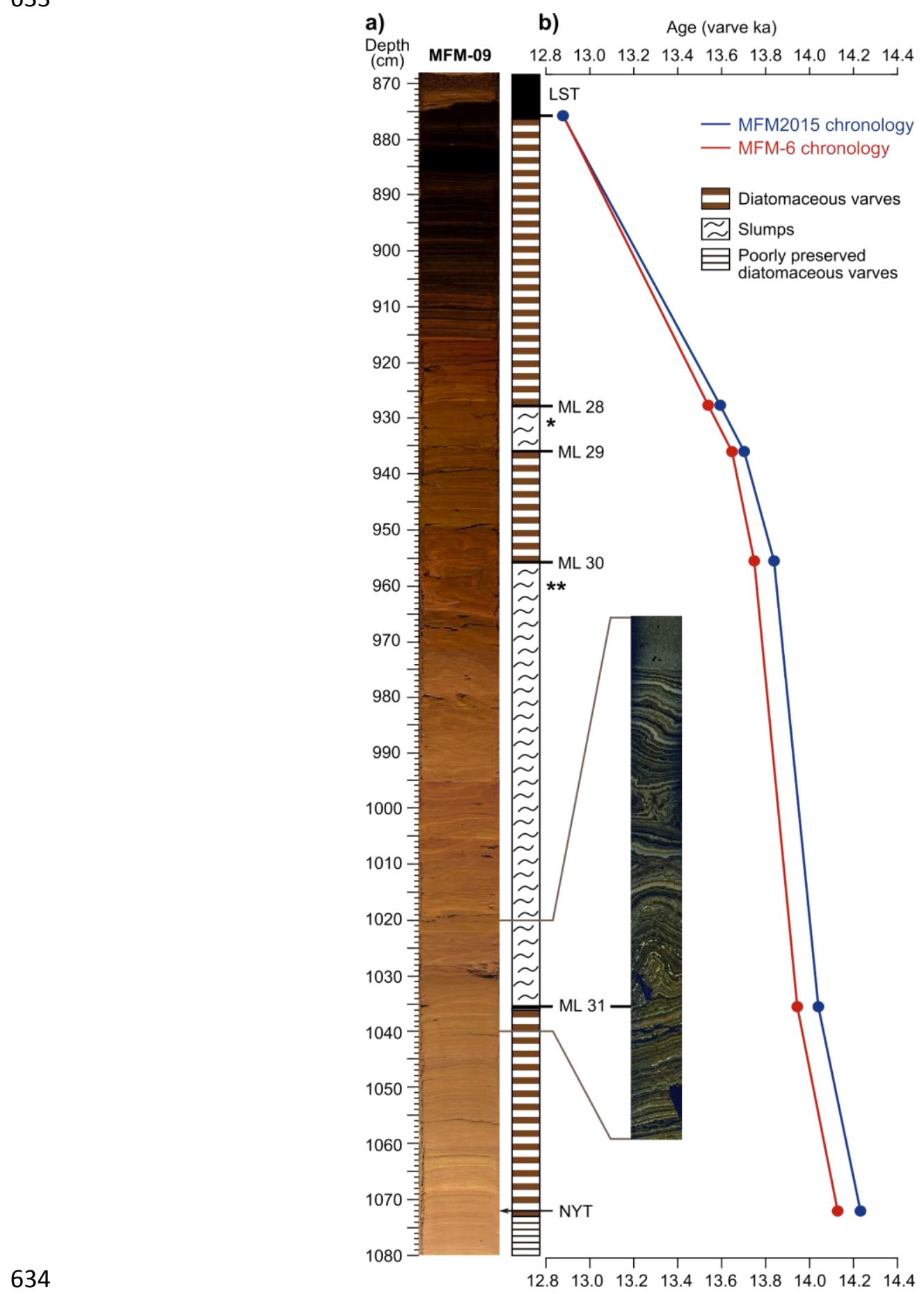


Figure 4:

636 Selected bi-plots showing tephra glass shard major, minor and trace element compositions. (a) The 637 full dataset from the analysed tephra layers in Meerfelder Maar, plotted using the Total Alkali Silica 638 classification by Le Bas et al. (1986). (b) The correlation of the trachytic-phonolitic shards from 639 MFM_T1067 to the Neapolitan Yellow Tuff (data from Tomlinson et al., 2012). (c) MFM_T876 640 correlated to the Laacher See Tephra (proximal glass data from the RESET database, (Bronk Ramsey 641 et al., in press-b). Also plotted are other layers containing reworked LST-like tephra (MFM_T548; MFM_T550; MFM_T685/687; MFM_T573; MFM_T876; MFM_T1130). A reduced dataset is plotted 643 for MFM_T685+687 for clarity. (d) MFM_T801 correlated to the Vedde Ash (composite of data from Lane et al., 2012b); MFM_T568 is compositionally indistinguishable on major elements. Error bar insets show approximate 2 sigma uncertainty range, based on precision of secondary standard glass analyses (supplementary information table 1). (e) Comparison of MFM_T334 to Holocene trachytic tephra from Western Ireland correlated to Jan Mayen (i.) and Mt Furnas in the Azores (Chambers et al., 2004; Reilly and Mitchell, 2014; Johannesson, in press) and MFM_T573 to published pantelleritic tephra correlated to eruptions of Pantelleria (Magny et al., 2011) and Jan Mayen (ii.) (Lacasse and

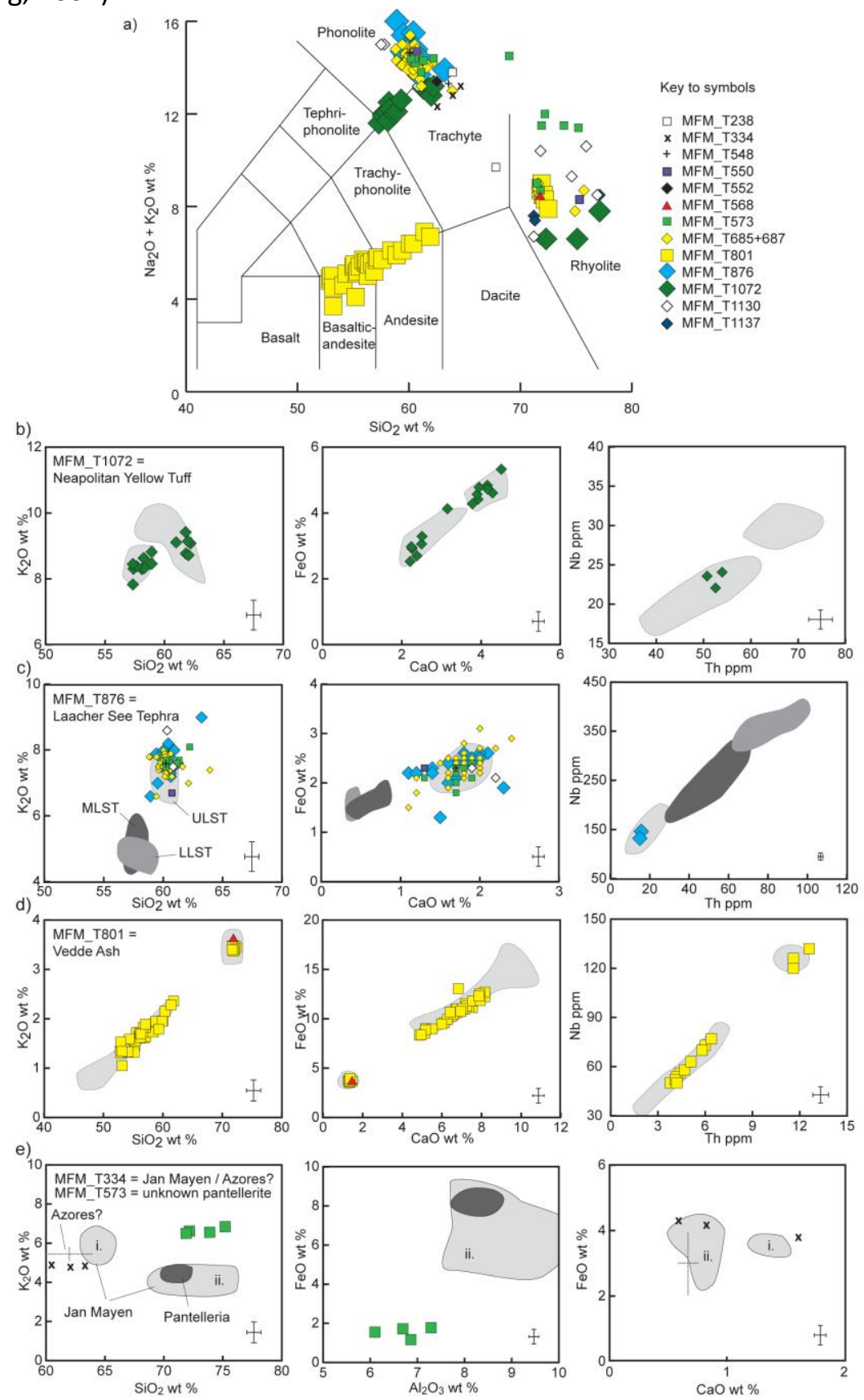


652

653 Lithological profile and summary of the Lateglacial and early Holocene tephrostratigraphy of Lake Meerfelder Maar, from the Ulmener Maar tephra to the onset of varve formation in MFM09 sequence.

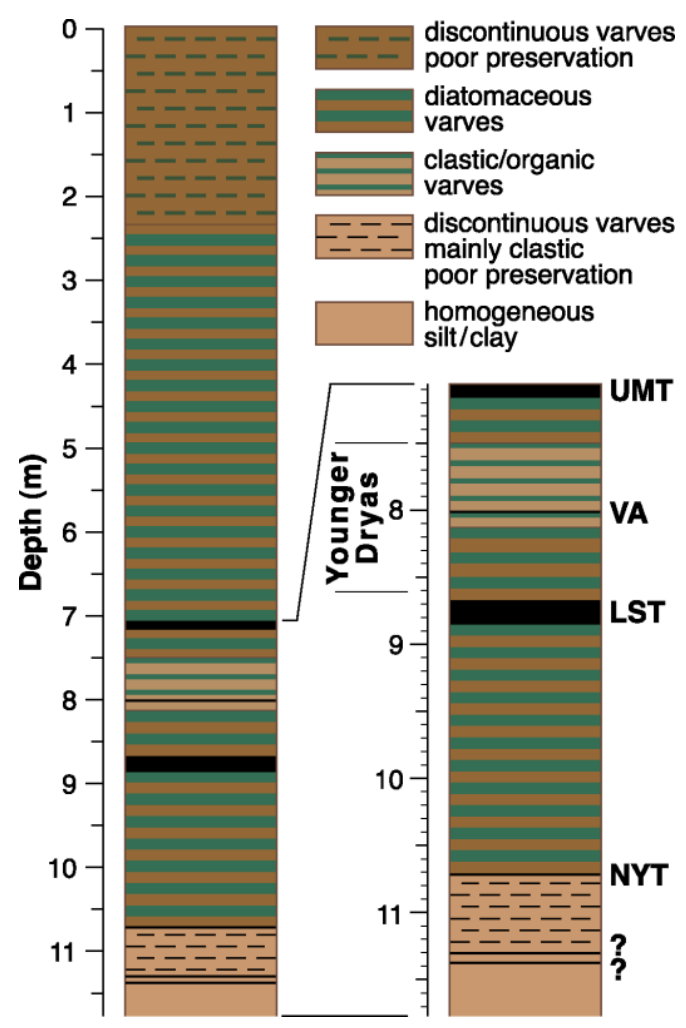

Figure 6:

Map showing the known distributions of tephra from the Neapolitan Yellow tuff (Lane et al., 2011a and references therein), the Laacher See Tephra (Riede et al., 2011 and references therein), and the Vedde Ash (Lane et al., 2012b and references therein). Key sites, and those where the tephra layers are co-located, are numbered: 1 . Meerfelder Maar, 2. NGRIP

(Mortensen et al., 2005); 3. Kråkenes (Mangerud et al., 1984); 4. Endinger Bruch (Lane et al., 2012c); 5. Rotmeer; 6. Soppensee; 7. Rotsee; 8. Lago Piccolo di Avigliana (Lane et al., 2012a); 9. Lake Bled (Lane et al., 2011a); 10. Lago Grande di Monticchio (Wulf et al., 2004).

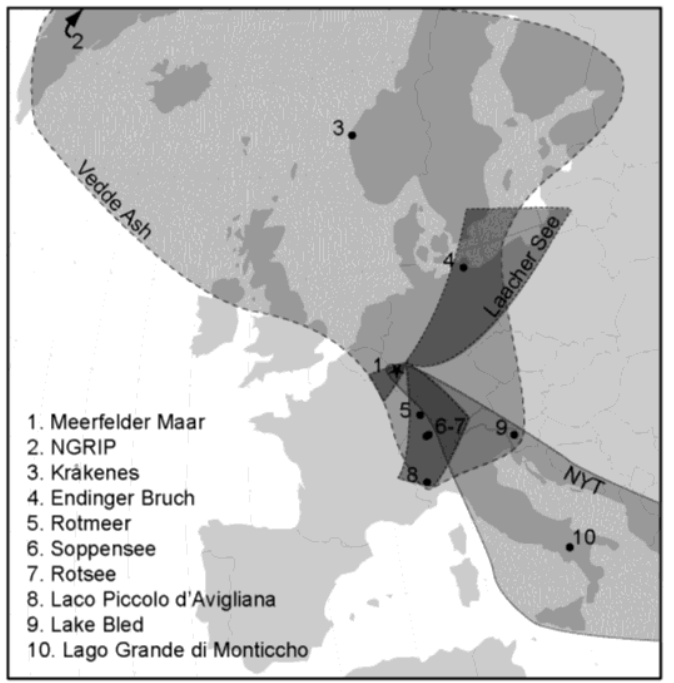


667 Table S1:

668 Complete datasets of single-shard major and minor element oxide compositions for all

669 tephra layers analysed within the Meerfelder Maar record, measured by electron

670 microprobe (section 2.3). Data are presented normalised to water-free compositions, with

671 original totals shown, after filtering points with analytical totals below 94 weight \%.

672 Secondary standard data, which provide a measure of precision and accuracy, are presented

673 within Supplementary Information (Table S2).

\begin{tabular}{|c|c|c|c|c|c|c|c|c|c|c|c|c|c|}
\hline & EPMA\# & $\mathrm{SiO}_{2}$ & $\mathrm{TiO}_{2}$ & $\overline{\mathrm{Al}_{2} \mathrm{O}_{3}}$ & $\mathrm{FeO}$ & MnO & $\mathrm{MgO}$ & $\mathrm{CaO}$ & $\mathrm{Na}_{2} \mathrm{O}$ & $\mathrm{K}_{2} \mathrm{O}$ & $\mathrm{P}_{2} \mathrm{O}_{5}$ & Total & Std file \\
\hline MFM T1137 & 1 & 71.82 & 0.02 & 13.93 & 3.53 & 0.19 & 1.61 & 2.28 & 2.70 & 3.91 & 0.00 & 96.79 & $a$ \\
\hline MFM T1137 & 2 & 71.20 & 0.23 & 14.94 & 3.22 & 0.09 & 1.01 & 1.75 & 3.90 & 3.67 & 0.01 & 99.08 & $a$ \\
\hline MFM T1137 & 3 & 71.27 & 0.37 & 14.91 & 3.12 & 0.07 & 1.04 & 1.77 & 3.91 & 3.51 & 0.02 & 99.24 & $\theta$ \\
\hline MFM T1137 & 4 & 77.09 & 0.06 & 12.71 & 1.05 & 0.01 & 0.03 & 0.56 & 3.79 & 4.70 & 0.00 & 94.42 & $\mathrm{e}$ \\
\hline & & $\mathrm{SiO}_{2}$ & $\mathrm{TiO}_{2}$ & $\mathrm{Al}_{2} \mathrm{O}_{3}$ & $\mathrm{FeO}$ & $\mathrm{MnO}$ & $\mathrm{MgO}$ & $\mathrm{CaO}$ & $\mathrm{Na}_{2} \mathrm{O}$ & $\mathrm{K}_{2} \mathrm{O}$ & $\mathrm{P}_{2} \mathrm{O}_{5}$ & Total & Std file \\
\hline MFM T1130 & 1 & 57.81 & 0.33 & 20.14 & 2.36 & \begin{tabular}{|l|}
0.17 \\
\end{tabular} & 0.67 & 3.49 & 6.18 & 8.81 & 0.05 & 96.77 & $f$ \\
\hline MFM T1130 & 2 & 57.46 & 0.43 & 20.00 & 2.62 & 0.14 & 0.94 & 3.38 & 6.11 & 8.92 & 0.00 & 97.49 & $\mathrm{a}$ \\
\hline MFM T1130 & 3 & 60.28 & 0.61 & 20.46 & 2.35 & 0.24 & 0.32 & 1.94 & 5.09 & 8.58 & 0.13 & 96.22 & $a$ \\
\hline MFM T1130 & 4 & 60.79 & 0.57 & 20.66 & 2.06 & 0.14 & 0.27 & 2.17 & 5.77 & 7.46 & 0.10 & 99.53 & $a$ \\
\hline MFM T1130 & 5 & 71.83 & 0.62 & 11.53 & 4.04 & 0.05 & 1.21 & 0.25 & 2.82 & 7.61 & 0.04 & 95.60 & f \\
\hline MFM T1130 & 6 & 71.17 & 0.45 & 13.14 & 4.19 & 0.14 & 1.52 & 2.61 & 2.67 & 4.04 & 0.08 & 98.05 & $g$ \\
\hline MFM T1130 & 8 & 74.60 & 0.12 & 12.17 & 2.15 & 0.01 & 0.81 & 0.89 & 2.55 & 6.70 & 0.01 & 95.50 & g \\
\hline MFM T1130 & 9 & 76.89 & 0.04 & 12.88 & 0.90 & 0.13 & 0.04 & 0.59 & 3.84 & 4.64 & 0.03 & 95.19 & $f$ \\
\hline & & $\mathrm{SiO}_{2}$ & $\mathrm{TiO}_{2}$ & $\mathrm{Al}_{2} \mathrm{O}_{3}$ & $\mathrm{FeO}$ & MnO & MgO & $\mathrm{CaO}$ & $\mathrm{Na}_{2} \mathrm{O}$ & $\mathrm{K}_{2} \mathrm{O}$ & $\mathrm{P}_{2} \mathrm{O}_{5}$ & Total & Std file \\
\hline MFM T1072 & 1 & 57.34 & 0.61 & 18.67 & 5.33 & \begin{tabular}{|l|}
0.10 \\
\end{tabular} & 1.50 & 4.51 & 3.80 & 7.83 & 0.30 & 94.91 & $f$ \\
\hline MFM T1072 & 2 & 57.67 & 0.55 & 19.12 & 4.76 & 0.05 & 1.36 & 4.19 & 3.51 & 8.50 & 0.31 & 95.46 & $\mathrm{e}$ \\
\hline MFM T1072 & 3 & 57.71 & 0.59 & 19.18 & 4.72 & 0.04 & 1.30 & 4.24 & 3.53 & \begin{tabular}{|l|}
8.36 \\
\end{tabular} & 0.32 & 97.62 & $\epsilon$ \\
\hline MFM T1072 & 4 & 57.98 & 0.50 & 18.87 & 4.63 & 0.01 & 1.24 & 4.31 & 3.70 & 8.43 & 0.32 & 97.36 & $\epsilon$ \\
\hline MFM T1072 & 5 & 58.10 & 0.58 & 18.80 & 4.84 & 0.11 & 1.37 & 4.16 & 3.44 & 8.30 & 0.31 & 96.23 & $a$ \\
\hline MFM T1072 & 6 & 58.25 & 0.54 & 18.66 & 4.57 & 0.17 & 1.22 & 3.90 & 3.83 & 8.63 & 0.23 & 95.92 & $f$ \\
\hline MFM_T1072 & 7 & 58.30 & 0.59 & 18.66 & 4.78 & 0.13 & 1.17 & 3.95 & 3.82 & 8.33 & 0.28 & 94.12 & $f$ \\
\hline MFM T1072 & 8 & 58.72 & 0.64 & 18.75 & 4.42 & 0.11 & 1.21 & 3.92 & 3.50 & 8.46 & 0.28 & 96.72 & $\mathrm{a}$ \\
\hline MFM T1072 & 9 & 58.93 & 0.48 & 18.92 & 4.28 & 0.14 & 1.13 & 3.78 & 3.59 & 8.46 & 0.29 & 97.74 & $a$ \\
\hline MFM T1072 & 10 & 59.29 & 0.48 & 19.14 & 4.15 & 0.06 & 0.94 & 3.17 & 3.69 & 8.87 & 0.20 & 94.72 & $\mathrm{e}$ \\
\hline MFM T1072 & 11 & 61.35 & 0.42 & 18.51 & 3.31 & 0.10 & 0.62 & 2.52 & 3.91 & 9.16 & 0.11 & 94.51 & $\mathrm{e}$ \\
\hline MFM T1072 & 12 & 61.78 & 0.40 & 18.56 & 3.06 & 0.14 & 0.54 & 2.50 & 3.52 & 9.42 & 0.08 & 97.63 & a \\
\hline MFM T1072 & 13 & 61.80 & 0.49 & 18.76 & 2.92 & 0.18 & 0.44 & 2.26 & 4.29 & \begin{tabular}{|l|l|}
8.77 \\
\end{tabular} & 0.10 & 97.28 & $a$ \\
\hline MFM T1072 & 14 & 61.98 & 0.40 & 18.77 & 2.70 & 0.06 & 0.47 & 2.38 & 3.99 & 9.14 & 0.10 & 95.49 & f \\
\hline MFM T1072 & 15 & 62.02 & 0.43 & 18.80 & 2.98 & 0.22 & 0.40 & 2.24 & 4.10 & 8.72 & 0.09 & 96.88 & $f$ \\
\hline MFM T1072 & 16 & 62.19 & 0.39 & 18.91 & 2.53 & 0.12 & 0.41 & 2.21 & 4.09 & 9.08 & 0.08 & 95.62 & $\mathrm{a}$ \\
\hline MFM T1072 & 17 & 75.14 & 0.15 & 14.16 & 1.74 & 0.05 & 0.76 & 1.15 & 2.44 & 4.13 & 0.29 & 96.60 & $f$ \\
\hline MFM T1072 & 18 & 72.34 & 0.59 & 12.92 & 3.64 & 0.24 & 1.98 & 1.68 & 3.20 & 3.38 & 0.02 & 99.46 & $f$ \\
\hline MFM T1072 & 19 & 77.08 & 0.14 & 11.82 & 2.38 & 0.08 & 0.02 & 0.69 & 4.41 & 3.38 & 0.01 & 96.26 & $\mathrm{f}$ \\
\hline & & $\mathrm{SiO}_{2}$ & $\mathrm{TiO}_{2}$ & $\mathrm{Al}_{2} \mathrm{O}_{3}$ & $\mathrm{FeO}$ & MnO & $\mathrm{MgO}$ & $\mathrm{CaO}$ & $\mathrm{Na}_{2} \mathrm{O}$ & $\mathrm{K}_{2} \mathrm{O}$ & $\mathrm{P}_{2} \mathrm{O}_{5}$ & Total & Std file \\
\hline MFM T876 & 1 & 58.91 & 0.29 & 21.21 & 2.22 & \begin{tabular}{|l|}
0.11 \\
\end{tabular} & 0.18 & 1.09 & 9.33 & 6.64 & 0.03 & 97.19 & $\mathrm{e}$ \\
\hline MFM T876 & 2 & 59.35 & 0.68 & 19.97 & 2.55 & 0.05 & 0.47 & 2.11 & 6.78 & 7.91 & 0.12 & 96.16 & $\mathrm{e}$ \\
\hline MFM T876 & 3 & 59.49 & 0.37 & 20.74 & 2.26 & 0.10 & 0.20 & 1.40 & 8.44 & 6.96 & 0.04 & 97.36 & $\mathrm{e}$ \\
\hline MFM T876 & 4 & 59.71 & 0.64 & 20.05 & 2.61 & 0.02 & 0.30 & 1.83 & 6.96 & 7.85 & 0.04 & 98.52 & $\mathrm{e}$ \\
\hline MFM T876 & 5 & 59.72 & 0.57 & 20.34 & 2.56 & 0.08 & 0.24 & 1.96 & 6.70 & 7.78 & 0.06 & 98.51 & $\mathrm{e}$ \\
\hline MFM T876 & 6 & 59.84 & 0.45 & 20.49 & 1.91 & 0.11 & 0.30 & 2.27 & 6.80 & 7.52 & 0.31 & 95.41 & $\mathrm{e}$ \\
\hline MFM_T876 & 7 & 59.88 & 0.58 & 20.08 & 2.45 & 0.09 & 0.30 & 1.93 & 6.68 & 7.90 & 0.10 & 96.06 & $\epsilon$ \\
\hline MFM T876 & 8 & 60.01 & 0.66 & 19.69 & 2.46 & 0.01 & 0.34 & 1.93 & 6.85 & 7.96 & 0.08 & 95.44 & $\epsilon$ \\
\hline MFM T876 & 9 & 60.41 & 0.57 & 20.05 & 2.36 & 0.11 & 0.28 & 1.75 & 6.73 & 7.70 & 0.05 & 98.36 & $\mathrm{~b}$ \\
\hline MFM T876 & 10 & 60.44 & 0.42 & 19.98 & 2.17 & 0.08 & 0.19 & 1.22 & 7.28 & 8.17 & 0.04 & 97.29 & $\mathrm{e}$ \\
\hline MFM_T876 & 11 & 60.53 & 0.57 & 20.02 & 2.08 & 0.09 & 0.25 & 1.71 & 6.86 & 7.82 & 0.08 & 97.31 & $\mathrm{e}$ \\
\hline MFM T876 & 12 & 60.54 & 0.61 & 19.82 & 2.45 & 0.20 & 0.28 & 1.79 & 6.41 & 7.81 & 0.09 & 97.55 & $\mathrm{~b}$ \\
\hline MFM T876 & 13 & 60.56 & 0.40 & 20.18 & 2.36 & 0.07 & 0.25 & 1.74 & 6.95 & 7.43 & 0.05 & 98.20 & $\mathrm{e}$ \\
\hline MFM T876 & 14 & 60.59 & 0.57 & 20.01 & 2.58 & 0.04 & 0.28 & 1.76 & 6.80 & 7.32 & 0.05 & 97.61 & $\mathrm{e}$ \\
\hline MFM T876 & 15 & 60.60 & 0.57 & 20.16 & 2.24 & 0.06 & 0.16 & 1.37 & 7.57 & 7.20 & 0.08 & 96.85 & $\mathrm{e}$ \\
\hline MFM T876 & 16 & 60.62 & 0.52 & 20.03 & 2.40 & 0.18 & 0.28 & 1.56 & 6.71 & 7.60 & 0.10 & 98.20 & $\mathrm{~b}$ \\
\hline MFM_T876 & 17 & 60.86 & 0.55 & 19.78 & 2.49 & 0.22 & 0.27 & 2.03 & 5.75 & 7.98 & 0.08 & 96.22 & $\mathrm{~b}$ \\
\hline MFM T876 & 18 & 61.18 & 0.48 & 19.89 & 2.03 & 0.16 & 0.27 & 1.61 & 6.74 & 7.57 & 0.06 & 98.59 & $\mathrm{~b}$ \\
\hline MFM T876 & 19 & 63.19 & \begin{tabular}{|l|}
0.33 \\
\end{tabular} & 19.62 & 1.26 & 0.07 & 0.12 & 1.49 & 4.87 & 9.03 & 0.03 & 99.07 & $\mathrm{~b}$ \\
\hline
\end{tabular}




\begin{tabular}{|c|c|c|c|c|c|c|c|c|c|c|c|c|c|}
\hline & & $\mathrm{SiO}_{2}$ & $\mathrm{TiO}_{2}$ & $\mathrm{Al}_{2} \mathrm{O}_{3}$ & $\mathrm{FeO}$ & MnO & $\mathrm{MgO}$ & $\mathrm{CaO}$ & $\mathrm{Na}_{2} \mathrm{O}$ & $\mathrm{K}_{2} \mathrm{O}$ & $\mathbf{P}_{2} \mathrm{O}_{5}$ & Total & Std file \\
\hline MFM_T801 & 1 & 52.88 & 3.58 & 13.61 & 12.26 & 0.21 & 3.93 & 8.18 & 3.45 & 1.36 & 0.54 & 96.93 & $\mathrm{c}$ \\
\hline MFM T801 & 2 & 52.90 & 3.59 & 13.50 & 12.54 & 0.20 & 3.95 & 7.91 & 3.61 & 1.31 & 0.49 & 96.65 & $\mathrm{c}$ \\
\hline MFM T801 & 3 & 52.96 & 5.15 & 12.95 & 13.06 & 0.24 & 3.45 & 6.84 & 3.44 & 1.53 & 0.38 & 96.03 & $\mathrm{c}$ \\
\hline MFM T801 & 4 & 53.16 & 3.55 & 13.57 & 12.32 & 0.23 & 3.90 & 7.87 & 3.62 & 1.34 & 0.43 & 96.64 & C \\
\hline MFM T801 & 5 & 53.21 & 3.44 & 13.47 & 12.70 & 0.28 & 3.81 & 8.17 & 3.15 & 1.32 & 0.46 & 97.52 & $\bar{c}$ \\
\hline MFM T801 & 6 & 53.22 & 2.84 & 10.70 & 11.80 & 0.20 & 7.17 & 10.06 & 2.63 & 1.05 & 0.33 & 98.06 & $\mathrm{c}$ \\
\hline MFM T801 & 7 & 54.14 & 3.45 & 13.46 & 11.85 & 0.28 & 3.83 & 7.95 & 3.23 & 1.33 & 0.48 & 96.25 & $\mathrm{c}$ \\
\hline MFM T801 & 8 & 54.43 & 3.12 & 13.77 & 11.81 & 0.20 & 3.58 & 7.55 & 3.49 & 1.59 & 0.46 & 96.73 & $\bar{c}$ \\
\hline MFM T801 & 9 & 55.01 & 3.23 & 13.52 & 11.54 & 0.19 & 3.50 & 7.20 & 3.81 & 1.57 & 0.43 & 98.42 & $\mathrm{c}$ \\
\hline MFM T801 & 10 & 55.05 & 3.18 & 13.69 & 11.14 & 0.13 & 3.47 & 7.36 & 3.96 & 1.58 & 0.43 & 98.25 & $\mathrm{c}$ \\
\hline MFM T801 & 11 & 55.20 & 2.13 & 10.85 & 10.11 & 0.37 & 6.50 & 10.46 & 2.77 & 1.33 & 0.29 & 97.54 & $\mathrm{c}$ \\
\hline MFM T801 & 12 & 55.32 & 3.26 & 13.12 & 11.14 & 0.18 & 3.92 & 7.55 & 3.66 & 1.46 & 0.40 & 95.01 & d \\
\hline MFM T801 & 13 & 55.39 & 3.17 & 13.64 & 11.28 & 0.15 & 3.49 & 7.27 & 3.61 & 1.56 & 0.44 & 97.23 & $c$ \\
\hline MFM T801 & 14 & 55.62 & 2.98 & 13.81 & 10.97 & 0.22 & 3.44 & 7.15 & 3.72 & 1.72 & 0.38 & 97.27 & $\mathrm{c}$ \\
\hline MFM T801 & 15 & 55.95 & 2.80 & 14.14 & 10.63 & 0.30 & 3.07 & 6.78 & 3.99 & 1.72 & 0.64 & 97.97 & c \\
\hline MFM T801 & 16 & 56.08 & 2.81 & 13.96 & 10.79 & 0.25 & 3.19 & 6.82 & 3.92 & 1.65 & 0.52 & 97.79 & c \\
\hline MFM T801 & 17 & 56.18 & 3.00 & 13.51 & 10.98 & 0.30 & 3.27 & 6.74 & 3.89 & 1.71 & 0.43 & 97.50 & $\mathrm{c}$ \\
\hline MFM T801 & 18 & 56.34 & 2.95 & 13.73 & 11.05 & 0.28 & 3.21 & 7.05 & 3.39 & 1.62 & 0.37 & 93.38 & $\mathrm{c}$ \\
\hline MFM_T801 & 19 & 56.35 & 2.84 & 13.56 & 10.75 & 0.21 & 3.37 & 6.95 & 3.83 & 1.69 & 0.45 & 98.19 & C \\
\hline MFM T801 & 20 & 56.72 & 2.69 & 13.54 & 10.97 & 0.22 & 3.11 & 6.71 & 3.82 & 1.82 & 0.38 & 97.89 & $\mathrm{C}$ \\
\hline MFM T801 & 21 & 56.93 & 2.88 & 13.36 & 10.92 & 0.12 & 3.29 & 6.95 & 3.60 & 1.61 & 0.34 & 97.68 & $\bar{d}$ \\
\hline MFM T801 & 22 & 57.12 & 2.68 & 14.13 & 10.26 & 0.16 & 2.89 & 6.50 & 4.07 & 1.64 & 0.55 & 98.51 & c \\
\hline MFM T801 & 23 & 57.21 & 2.61 & 13.65 & 10.50 & 0.16 & 3.13 & 6.59 & 3.96 & 1.83 & 0.37 & 97.28 & $\mathrm{c}$ \\
\hline MFM T801 & 24 & 57.62 & 2.51 & 14.17 & 9.95 & 0.28 & 2.83 & 6.28 & 4.02 & 1.73 & 0.62 & 95.58 & $\mathrm{c}$ \\
\hline MFM T801 & 25 & 58.43 & 2.25 & 14.30 & 9.48 & 0.19 & 2.60 & 5.98 & 4.38 & 1.73 & 0.67 & 98.30 & $\mathrm{c}$ \\
\hline MFM T801 & 26 & 58.86 & 2.42 & 13.50 & 9.60 & 0.18 & 3.05 & 6.13 & 3.94 & 1.95 & 0.37 & 96.83 & $\mathrm{C}$ \\
\hline MFM_T801 & 27 & 59.35 & 2.08 & 14.57 & 8.98 & 0.29 & 2.38 & 5.51 & 4.33 & 1.79 & 0.70 & 98.22 & $\mathrm{c}$ \\
\hline MFM T801 & 28 & 60.07 & 1.91 & 14.40 & 9.00 & 0.26 & 2.24 & 5.18 & 4.39 & 1.97 & 0.58 & 97.66 & $\mathrm{C}$ \\
\hline MFM T801 & 29 & 60.39 & 0.60 & 20.17 & 2.26 & 0.09 & 0.29 & 1.82 & 6.50 & 7.83 & 0.06 & 97.02 & $\mathrm{c}$ \\
\hline MFM T801 & 30 & 60.42 & 2.13 & 14.28 & 8.88 & 0.23 & 2.10 & 5.18 & 4.25 & 2.15 & 0.38 & 97.40 & $c$ \\
\hline MFM T801 & 31 & 61.44 & 1.81 & 13.81 & 8.37 & 0.19 & 2.17 & 4.95 & 4.64 & 2.28 & 0.35 & 98.67 & 0 \\
\hline MFM T801 & 32 & 61.88 & 1.66 & 13.96 & 8.35 & 0.17 & 2.08 & 4.87 & 4.34 & 2.36 & 0.33 & 97.51 & $\mathrm{c}$ \\
\hline MFM T801 & 34 & 71.78 & 0.34 & 13.39 & 3.95 & 0.14 & 0.22 & 1.36 & 5.34 & 3.40 & 0.08 & 97.05 & $\mathrm{~d}$ \\
\hline MFM_T801 & 35 & 71.85 & 0.29 & 13.43 & 3.68 & 0.20 & 0.20 & 1.47 & 5.35 & 3.47 & 0.06 & 95.58 & $\mathrm{~d}$ \\
\hline MFM T801 & 36 & 71.86 & 0.28 & 13.56 & 3.55 & 0.17 & 0.19 & 1.34 & 5.51 & 3.48 & 0.05 & 98.62 & $\bar{d}$ \\
\hline MFM T801 & 37 & 72.01 & 0.34 & 13.71 & 3.71 & 0.17 & 0.18 & 1.36 & 5.09 & 3.37 & 0.06 & 99.20 & $\mathrm{~d}$ \\
\hline MFM T801 & 38 & 72.15 & 0.27 & 13.60 & 3.68 & 0.18 & 0.20 & 1.43 & 5.00 & 3.49 & 0.01 & 98.22 & d \\
\hline MFM T801 & 39 & 72.25 & 0.34 & 13.76 & 3.65 & 0.13 & 0.20 & 1.30 & 4.87 & 3.42 & 0.07 & 94.40 & $\bar{d}$ \\
\hline MFM T801 & 40 & 72.50 & 0.28 & 13.79 & 3.80 & 0.18 & 0.21 & 1.28 & 4.49 & 3.46 & 0.03 & 96.67 & $\bar{d}$ \\
\hline & & $\mathrm{SiO}_{2}$ & $\mathrm{TiO}_{2}$ & $\overline{\mathrm{Al}_{2} \mathrm{O}_{3}}$ & $\mathrm{FeO}$ & MnO & $\mathrm{MgO}$ & $\mathrm{CaO}$ & $\mathrm{Na}_{2} \mathrm{O}$ & $\mathrm{K}_{2} \mathrm{O}$ & $\mathrm{P}_{2} \mathrm{O}_{5}$ & Total & Std file \\
\hline MFM_T687 & 1 & 58.90 & 0.92 & 20.10 & 2.87 & 0.03 & 0.33 & 2.42 & 6.54 & 7.78 & 0.12 & 96.57 & $\mathrm{e}$ \\
\hline MFM_T687 & 2 & 59.86 & 0.58 & 20.22 & 2.42 & 0.10 & 0.32 & 1.88 & 6.89 & 7.64 & 0.09 & 95.85 & $\mathrm{c}$ \\
\hline MFM T687 & 3 & 59.82 & 0.63 & 20.10 & 2.24 & 0.14 & 0.31 & 1.75 & 7.37 & 7.57 & 0.07 & 96.51 & $\mathrm{c}$ \\
\hline MFM T687 & 4 & 60.21 & 0.60 & 20.28 & 2.49 & 0.05 & 0.28 & 1.91 & 6.42 & 7.70 & 0.06 & 96.19 & $\epsilon$ \\
\hline MFM T687 & 5 & 60.13 & 0.60 & 20.16 & 2.35 & 0.04 & 0.32 & 1.87 & 6.59 & 7.88 & 0.07 & 96.41 & $\epsilon$ \\
\hline MFM T687 & 6 & 59.96 & 0.62 & 20.44 & 2.36 & 0.08 & 0.30 & 1.95 & 6.37 & 7.88 & 0.05 & 96.73 & $\bar{e}$ \\
\hline MFM T687 & 7 & 58.76 & 0.87 & 19.88 & 3.08 & 0.06 & 0.45 & 1.95 & 7.06 & 7.78 & 0.11 & 98.75 & $\overline{\mathrm{e}}$ \\
\hline MFM T687 & 8 & 59.67 & 0.62 & 20.03 & 2.56 & 0.06 & 0.29 & 2.04 & 6.96 & 7.50 & 0.27 & 97.29 & $\epsilon$ \\
\hline MFM T687 & 9 & 59.43 & 0.37 & 21.23 & 1.92 & 0.21 & 0.15 & 1.60 & 8.46 & 6.56 & 0.06 & 97.78 & $a$ \\
\hline MFM T687 & 10 & 60.01 & 0.63 & 19.99 & 2.27 & 0.02 & 0.32 & 1.97 & 6.68 & 8.05 & 0.07 & 96.88 & $\mathrm{e}$ \\
\hline MFM T687 & 11 & 60.05 & 0.63 & 20.03 & 2.30 & 0.06 & 0.32 & 2.06 & 5.43 & 8.95 & 0.18 & 97.00 & $\mathrm{e}$ \\
\hline MFM T687 & 12 & 60.07 & 0.60 & 20.51 & 2.30 & 0.06 & 0.32 & 1.83 & 6.79 & 7.43 & 0.09 & 97.09 & $\mathrm{e}$ \\
\hline MFM T687 & 13 & 60.28 & 0.57 & 20.05 & 2.50 & 0.21 & 0.32 & 1.75 & 7.02 & 7.23 & 0.07 & 96.86 & $a$ \\
\hline MFM T687 & 14 & 60.11 & 0.49 & 20.23 & 2.36 & 0.08 & 0.30 & 1.84 & 6.85 & 7.69 & 0.05 & 97.21 & $\bar{e}$ \\
\hline MFM_T687 & 15 & 60.31 & 0.63 & 20.30 & 2.42 & 0.12 & 0.30 & 1.81 & 6.39 & 7.64 & 0.07 & 96.99 & $\bar{a}$ \\
\hline MFM_T687 & 16 & 60.25 & 0.58 & 20.38 & 2.48 & 0.15 & 0.32 & 1.86 & 6.54 & 7.37 & 0.08 & 97.17 & $a$ \\
\hline MFM T687 & 17 & 59.27 & 0.74 & 20.01 & 2.90 & 0.17 & 0.44 & 2.26 & 6.88 & 7.23 & 0.10 & 987.7 & \\
\hline
\end{tabular}




\begin{tabular}{|c|c|c|c|c|c|c|c|c|c|c|c|c|c|}
\hline MFM T687 & 18 & 59.88 & 0.55 & 20.14 & 2.52 & 0.04 & 0.33 & 1.85 & 7.02 & 7.59 & 0.08 & 97.84 & $\mathrm{e}$ \\
\hline MFM T687 & 19 & 59.70 & 0.58 & 20.50 & 2.40 & 0.09 & 0.25 & 1.83 & 6.97 & 7.62 & 0.06 & 98.22 & $\mathrm{e}$ \\
\hline MFM T687 & 20 & 60.06 & 0.56 & 20.26 & 2.48 & 0.09 & 0.34 & 1.92 & 6.38 & 7.83 & 0.07 & 97.75 & $\mathrm{e}$ \\
\hline MFM T687 & 21 & 59.86 & 0.55 & 20.44 & 2.20 & 0.15 & 0.27 & 2.00 & 6.61 & 7.84 & 0.08 & 98.08 & $a$ \\
\hline MFM T687 & 22 & 60.04 & 0.58 & 20.19 & 2.55 & 0.05 & 0.33 & 1.84 & 6.62 & 7.76 & 0.04 & 97.84 & $\mathrm{e}$ \\
\hline MFM T687 & 23 & 60.25 & 0.57 & 20.42 & 2.29 & 0.11 & 0.33 & 1.87 & 6.53 & 7.49 & 0.14 & 97.58 & $a$ \\
\hline MFM T687 & 24 & 60.23 & 0.62 & 19.70 & 2.51 & 0.13 & 0.36 & 2.03 & 7.01 & 7.33 & 0.09 & 97.67 & $\overline{\mathrm{e}}$ \\
\hline MFM T687 & 25 & 60.56 & 0.46 & 20.39 & 2.21 & 0.16 & 0.28 & 1.61 & 6.62 & 7.65 & 0.05 & 97.20 & $a$ \\
\hline MFM T687 & 26 & 60.39 & 0.51 & 20.46 & 2.21 & 0.10 & 0.28 & 1.75 & 6.75 & 7.47 & 0.07 & 97.50 & $a$ \\
\hline MFM T687 & 27 & 60.12 & 0.29 & 20.78 & 1.84 & 0.13 & 0.15 & 1.24 & 8.24 & 7.18 & 0.02 & 97.93 & $\mathrm{e}$ \\
\hline MFM T687 & 28 & 60.15 & 0.56 & 20.18 & 2.46 & 0.07 & 0.29 & 1.85 & 6.73 & 7.67 & 0.05 & 97.93 & $\mathrm{e}$ \\
\hline MFM T687 & 29 & 60.45 & 0.48 & 20.23 & 2.08 & 0.12 & 0.28 & 1.81 & 6.59 & 7.90 & 0.07 & 97.49 & $\mathrm{e}$ \\
\hline MFM T687 & 30 & 60.13 & 0.50 & 20.26 & 2.23 & 0.10 & 0.31 & 1.83 & 6.64 & 7.94 & 0.08 & 98.14 & $\mathrm{e}$ \\
\hline MFM_T687 & 31 & 60.28 & 0.47 & 20.42 & 2.12 & 0.07 & 0.24 & 1.60 & 6.94 & 7.81 & 0.05 & 98.05 & $\mathrm{e}$ \\
\hline MFM T687 & 32 & 60.14 & 0.60 & 19.87 & 2.62 & 0.25 & 0.30 & 2.01 & 6.95 & 7.16 & 0.10 & 98.30 & $a$ \\
\hline MFM T687 & 33 & 60.37 & 0.54 & 20.53 & 2.23 & 0.00 & 0.30 & 1.72 & 6.66 & 7.60 & 0.06 & 97.95 & $\mathrm{e}$ \\
\hline MFM T687 & 34 & 60.21 & 0.48 & 20.37 & 2.27 & 0.15 & 0.29 & 1.82 & 6.74 & 7.59 & 0.08 & 98.21 & $a$ \\
\hline MFM T687 & 35 & 60.50 & 0.34 & 20.63 & 1.85 & 0.08 & 0.15 & 1.42 & 7.29 & 7.68 & 0.06 & 97.84 & $\mathrm{e}$ \\
\hline MFM T687 & 36 & 60.19 & 0.55 & 20.29 & 2.25 & 0.17 & 0.25 & 1.82 & 6.78 & 7.62 & 0.09 & 98.38 & $a$ \\
\hline MFM T687 & 37 & 60.35 & 0.51 & 20.13 & 2.11 & 0.19 & 0.30 & 1.79 & 6.77 & 7.72 & 0.11 & 98.24 & $a$ \\
\hline MFM T687 & 38 & 60.18 & 0.61 & 20.03 & 2.30 & 0.15 & 0.33 & 1.88 & 6.59 & 7.86 & 0.08 & 98.87 & $a$ \\
\hline MFM T687 & 39 & 60.01 & 0.57 & 20.20 & 2.23 & 0.18 & 0.37 & 2.01 & 6.63 & 7.75 & 0.07 & 99.22 & $a$ \\
\hline MFM T687 & 40 & 60.56 & 0.68 & 19.35 & 2.75 & 0.22 & 0.35 & 1.80 & 6.73 & 7.45 & 0.09 & 98.44 & $a$ \\
\hline MFM T687 & 41 & 60.70 & 0.23 & 20.77 & 1.86 & 0.21 & 0.16 & 1.21 & 7.77 & 7.06 & 0.03 & 98.56 & $a$ \\
\hline MFM T687 & 42 & 60.69 & 0.42 & 20.59 & 2.12 & 0.14 & 0.20 & 1.20 & 7.35 & 7.25 & 0.04 & 99.02 & $a$ \\
\hline MFM T687 & 43 & 62.12 & 0.21 & 20.49 & 1.54 & 0.15 & 0.15 & 1.11 & 7.21 & 7.00 & 0.02 & 97.74 & $a$ \\
\hline MFM T687 & 44 & 61.68 & 0.33 & 20.69 & 1.67 & 0.15 & 0.15 & 1.22 & 7.13 & 6.93 & 0.06 & 98.46 & $a$ \\
\hline MFM T687 & 45 & 61.60 & 0.56 & 19.37 & 2.09 & 0.19 & 0.35 & 1.78 & 6.42 & 7.53 & 0.10 & 99.31 & $a$ \\
\hline MFM T687 & 46 & 63.95 & 0.62 & 18.02 & 2.42 & 0.08 & 0.31 & 1.49 & 5.64 & 7.37 & 0.11 & 98.64 & $a$ \\
\hline MFM T687 & 47 & 71.57 & 0.30 & 13.95 & 3.64 & 0.19 & 0.24 & 1.45 & 5.10 & 3.47 & 0.09 & 97.26 & $a$ \\
\hline MFM T687 & 48 & 71.64 & 0.30 & 13.69 & 3.78 & 0.13 & 0.22 & 1.35 & 5.36 & 3.47 & 0.05 & 97.33 & $a$ \\
\hline MFM T687 & 49 & 71.61 & 0.32 & 13.54 & 3.93 & 0.00 & 0.19 & 1.41 & 5.36 & 3.59 & 0.05 & 97.38 & $\mathrm{e}$ \\
\hline MFM T687 & 50 & 71.61 & 0.31 & 13.72 & 3.69 & 0.04 & 0.20 & 1.35 & 5.43 & 3.61 & 0.04 & 97.96 & $\overline{\mathrm{e}}$ \\
\hline MFM T687 & 51 & 71.45 & 0.27 & 13.78 & 3.95 & 0.14 & 0.22 & 1.34 & 5.27 & 3.52 & 0.06 & 98.85 & $a$ \\
\hline MFM T687 & 52 & 74.93 & 0.39 & 13.69 & 2.28 & 0.00 & 0.47 & 0.33 & 2.64 & 5.20 & 0.07 & 94.66 & $\mathrm{c}$ \\
\hline & & $\mathrm{SiO}_{2}$ & $\mathrm{TiO}_{2}$ & $\mathrm{Al}_{2} \mathrm{O}_{3}$ & $\mathrm{FeO}$ & MnO & $\mathrm{MgO}$ & $\mathrm{CaO}$ & $\mathrm{Na}_{2} \mathrm{O}$ & $\mathrm{K}_{2} \mathrm{O}$ & $\mathrm{P}_{2} \mathrm{O}_{5}$ & Total & Std file \\
\hline MFM T685 & 1 & 60.60 & 0.60 & 20.00 & 2.41 & 0.13 & 0.31 & 2.03 & 5.90 & 7.91 & 0.11 & 94.55 & $\mathrm{c}$ \\
\hline MFM T685 & 2 & 60.16 & 0.54 & 19.94 & 2.33 & 0.18 & 0.33 & 1.86 & 6.74 & 7.82 & 0.09 & 95.57 & c \\
\hline MFM T685 & 3 & 60.07 & 0.52 & 20.09 & 2.52 & 0.21 & 0.28 & 1.65 & 6.77 & 7.79 & 0.08 & 95.89 & c \\
\hline MFM T685 & 4 & 59.63 & 0.68 & 20.24 & 2.67 & 0.19 & 0.32 & 1.97 & 6.85 & 7.36 & 0.08 & 97.16 & $\mathrm{c}$ \\
\hline MFM_T685 & 5 & 60.48 & 0.29 & 20.71 & 1.96 & 0.20 & 0.18 & 1.42 & 7.80 & 6.89 & 0.07 & 96.20 & $a$ \\
\hline MFM T685 & 6 & 59.60 & 0.67 & 20.18 & 2.69 & 0.16 & 0.35 & 2.03 & 6.79 & 7.46 & 0.08 & 97.67 & $a$ \\
\hline MFM T685 & 7 & 59.37 & 0.63 & 20.37 & 2.70 & 0.14 & 0.35 & 2.19 & 6.29 & 7.82 & 0.13 & 98.25 & $a$ \\
\hline MFM T685 & 8 & 60.34 & 0.49 & 20.34 & 2.17 & 0.15 & 0.24 & 1.65 & 6.77 & 7.77 & 0.07 & 97.25 & $\mathrm{c}$ \\
\hline MFM T685 & 9 & 60.20 & 0.55 & 20.30 & 2.26 & 0.15 & 0.29 & 1.82 & 6.73 & 7.65 & 0.07 & 97.55 & c \\
\hline MFM T685 & 10 & 60.13 & 0.56 & 20.48 & 2.32 & 0.20 & 0.30 & 1.81 & 6.67 & 7.45 & 0.07 & 97.77 & $a$ \\
\hline MFM T685 & 11 & 60.41 & 0.56 & 20.25 & 2.17 & 0.10 & 0.27 & 1.87 & 6.49 & 7.68 & 0.18 & 97.47 & $a$ \\
\hline MFM T685 & 12 & 60.97 & 0.62 & 20.04 & 2.52 & 0.06 & 0.30 & 1.88 & 6.06 & 7.46 & 0.10 & 96.70 & c \\
\hline MFM T685 & 13 & 60.21 & 0.60 & 20.28 & 2.43 & 0.18 & 0.28 & 1.69 & 6.82 & 7.45 & 0.06 & 98.19 & c \\
\hline MFM T685 & 14 & 60.38 & 0.63 & 20.21 & 2.48 & 0.21 & 0.32 & 1.97 & 6.25 & 7.45 & 0.10 & 97.94 & c \\
\hline MFM T685 & 15 & 59.88 & 0.74 & 20.16 & 2.76 & 0.19 & 0.44 & 1.82 & 6.41 & 7.49 & 0.12 & 99.16 & $a$ \\
\hline MFM_T685 & 16 & 59.98 & 0.53 & 20.09 & 2.39 & 0.27 & 0.29 & 1.85 & 7.04 & 7.49 & 0.08 & 99.01 & $a$ \\
\hline MFM T685 & 17 & 61.13 & 0.71 & 19.60 & 2.80 & 0.30 & 0.35 & 1.87 & 6.21 & 6.96 & 0.08 & 97.45 & $a$ \\
\hline MFM T685 & 18 & 60.42 & 0.62 & 20.31 & 2.27 & 0.20 & 0.31 & 1.93 & 6.25 & 7.62 & 0.08 & 98.76 & C \\
\hline MFM T685 & 19 & 60.76 & 0.41 & 20.45 & 2.18 & 0.14 & 0.22 & 1.69 & 6.59 & 7.45 & 0.10 & 98.33 & $a$ \\
\hline MFM T685 & 20 & 60.59 & 0.45 & 20.12 & 2.18 & 0.12 & 0.30 & 1.85 & 6.64 & 7.69 & 0.06 & 98.97 & $a$ \\
\hline MFM T685 & 21 & 71.63 & 0.29 & 13.62 & 3.70 & 0.09 & 0.26 & 1.37 & 5.39 & 3.61 & 0.03 & 98.54 & $\overline{\mathrm{e}}$ \\
\hline MFM T685 & 22 & 71.45 & 0.27 & 13.78 & 3.95 & 0.14 & 0.22 & 1.34 & 5.27 & 3.52 & 0.06 & 98.85 & $a$ \\
\hline MFM T685 & 23 & 75.70 & 0.27 & 13.10 & 1.66 & 0.06 & 0.16 & 0.23 & 2.53 & 6.15 & 0.13 & 95.85 & $a$ \\
\hline & & $\mathrm{SiO}_{2}$ & $\mathrm{TiO}_{2}$ & $\mathrm{Al}_{2} \mathrm{O}_{3}$ & $\mathrm{FeO}$ & MnO & $\mathrm{MgO}$ & $\mathrm{CaO}$ & $\mathrm{Na}_{2} \mathrm{O}$ & $\mathrm{K}_{2} \mathrm{O}$ & $\mathrm{P}_{2} \mathrm{O}_{5}$ & Total & Std file \\
\hline MFM T573 & 1 & 60.40 & 0.56 & 19.81 & 2.41 & $\begin{array}{l}0.17 \\
\end{array}$ & \begin{tabular}{|c|}
0.31 \\
\end{tabular} & 1.95 & $\begin{array}{l}6.58 \\
\end{array}$ & 7.72 & 0.09 & 97.57 & $\mathrm{~g}$ \\
\hline MFM T573 & 2 & 60.60 & 0.55 & 20.02 & 2.25 & 0.20 & 0.31 & 1.83 & 6.60 & 7.55 & 0.09 & 97.45 & $g$ \\
\hline MFM T573 & 3 & 60.48 & 0.46 & 20.25 & 2.21 & 0.23 & 0.22 & 1.69 & 6.81 & 7.56 & 0.08 & 97.88 & $g$ \\
\hline MFM T573 & 4 & 60.20 & 0.39 & 20.39 & 2.33 & 0.24 & 0.23 & 1.68 & 6.98 & 7.53 & 0.05 & 98.68 & $f$ \\
\hline MFM T573 & 5 & 60.18 & 0.47 & 20.45 & 2.11 & 0.17 & 0.24 & 1.86 & 6.73 & 7.69 & 0.10 & 99.33 & $a$ \\
\hline MFM T573 & 6 & 61.29 & 0.38 & 20.22 & 1.77 & 0.05 & 0.20 & 1.72 & 6.63 & 7.70 & 0.04 & 97.66 & $g$ \\
\hline MFM T573 & 7 & 61.11 & 0.39 & 20.52 & 2.02 & 0.20 & 0.21 & 1.67 & 6.21 & 7.60 & 0.07 & 98.90 & $f$ \\
\hline MFM T573 & 8 & 62.19 & 0.33 & 19.12 & 2.06 & 0.13 & 0.42 & 1.33 & 6.26 & 8.12 & 0.02 & 99.28 & $g$ \\
\hline MFM T573 & 9 & 71.81 & 0.30 & 13.56 & 3.76 & 0.20 & 0.23 & 1.36 & 5.09 & 3.64 & 0.06 & 96.52 & $g$ \\
\hline MFM T573 & 10 & 71.48 & 0.28 & 13.50 & 4.01 & 0.13 & 0.21 & 1.34 & 5.50 & 3.50 & 0.03 & 97.87 & $g$ \\
\hline MFM T573 & 11 & 69.00 & 0.69 & 7.45 & 4.68 & 0.11 & 1.60 & 1.89 & 5.93 & 8.59 & 0.06 & 98.65 & $f$ \\
\hline MFM T573 & 12 & 72.21 & 0.46 & 7.29 & 3.38 & 0.09 & 1.78 & 2.71 & 5.39 & \begin{tabular}{|l|}
6.62 \\
\end{tabular} & 0.08 & 98.48 & $g$ \\
\hline MFM T573 & 13 & 71.93 & 0.60 & 6.69 & 4.38 & 0.10 & 1.72 & 3.00 & 5.04 & 6.51 & 0.05 & 98.93 & $f$ \\
\hline MFM T573 & 14 & 73.93 & 0.18 & 6.10 & 3.82 & 0.08 & 1.55 & 2.81 & 4.95 & 6.54 & 0.03 & 96.86 & $f$ \\
\hline MFM T573 & 15 & 75.25 & 0.11 & 6.86 & 3.00 & 0.05 & 1.17 & 2.17 & 4.56 & 6.81 & 0.02 & 98.94 & $g$ \\
\hline
\end{tabular}




\begin{tabular}{|c|c|c|c|c|c|c|c|c|c|c|c|c|c|}
\hline \multirow{3}{*}{ MFM T568 } & & $\mathrm{SiO}_{2}$ & $\mathrm{TiO}_{2}$ & $\mathrm{Al}_{2} \mathrm{O}_{3}$ & $\mathrm{FeO}$ & MnO & $\mathrm{MgO}$ & $\mathrm{CaO}$ & $\mathrm{Na}_{2} \mathrm{O}$ & $\mathrm{K}_{2} \mathrm{O}$ & $\mathrm{P}_{2} \mathrm{O}_{5}$ & Total & Std file \\
\hline & 1 & 71.76 & 0.30 & 13.96 & 3.69 & 0.13 & 0.21 & 1.37 & 4.89 & 3.63 & 0.06 & 98.49 & $a$ \\
\hline & & $\mathrm{SiO}_{2}$ & $\mathrm{TiO}_{2}$ & $\mathrm{Al}_{2} \mathrm{O}_{3}$ & $\mathrm{FeO}$ & MnO & MgO & $\mathrm{CaO}$ & $\mathrm{Na}_{2} \mathrm{O}$ & $\mathrm{K}_{2} \mathrm{O}$ & $\mathrm{P}_{2} \mathrm{O}_{5}$ & Total & Std file \\
\hline \multirow[t]{2}{*}{ MFM T552 } & 1 & 62.49 & 0.64 & 19.03 & 2.22 & 0.24 & 0.34 & 1.49 & 6.40 & 7.04 & 0.12 & 100.33 & 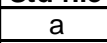 \\
\hline & & $\mathrm{SiO}_{2}$ & $\mathrm{TiO}_{2}$ & $\mathrm{Al}_{2} \mathrm{O}_{3}$ & $\mathrm{FeO}$ & $\mathrm{MnO}$ & $\mathrm{MgO}$ & $\mathrm{CaO}$ & $\mathrm{Na}_{2} \mathrm{O}$ & $\mathrm{K}_{2} \mathrm{O}$ & $\mathrm{P}_{2} \mathrm{O}_{5}$ & Total & Std file \\
\hline MFM T550 & 1 & 60.68 & 0.61 & 19.83 & 2.30 & 0.19 & 0.28 & 1.34 & 7.95 & 6.75 & 0.08 & 97.18 & $f$ \\
\hline \multirow{2}{*}{ MFM_T550 } & 2 & 75.26 & 0.49 & 13.70 & 1.33 & 0.11 & 0.36 & 0.46 & 3.59 & 4.70 & 0.02 & 95.67 & $f$ \\
\hline & & $\mathrm{SiO}_{2}$ & $\mathrm{TiO}_{2}$ & $\mathrm{Al}_{2} \mathrm{O}_{3}$ & $\mathrm{FeO}$ & MnO & MgO & $\mathrm{CaO}$ & $\mathrm{Na}_{2} \mathrm{O}$ & $\mathrm{K}_{2} \mathrm{O}$ & $\mathrm{P}_{2} \mathrm{O}_{5}$ & Total & Std file \\
\hline MFM T548 & 1 & 60.25 & 0.52 & 20.10 & 2.30 & 0.23 & 0.25 & 1.71 & 7.01 & 7.58 & 0.05 & 98.78 & $f$ \\
\hline \multirow[t]{2}{*}{ MFM T548 } & $\overline{2}$ & 63.61 & 0.27 & 17.96 & 3.66 & 0.27 & 0.19 & 0.70 & 7.98 & 5.31 & 0.04 & 98.33 & $f$ \\
\hline & & $\mathrm{SiO}_{2}$ & $\mathrm{TiO}_{2}$ & $\mathrm{Al}_{2} \mathrm{O}_{3}$ & $\mathrm{FeO}$ & MnO & $\mathrm{MgO}$ & $\mathrm{CaO}$ & $\mathrm{Na}_{2} \mathrm{O}$ & $\mathrm{K}_{2} \mathrm{O}$ & $\mathbf{P}_{2} \mathbf{O}_{5}$ & Total & Std file \\
\hline MFM_T334 & 1 & 62.49 & 0.64 & 17.99 & 3.92 & 0.21 & 0.58 & 1.67 & 7.30 & 5.00 & 0.20 & 96.73 & $f$ \\
\hline MFM_T334 & 2 & 63.88 & 0.41 & 17.16 & 4.28 & 0.24 & 0.28 & 0.86 & 7.95 & 4.87 & 0.08 & 97.18 & $f$ \\
\hline \multirow[t]{2}{*}{ MFM T334 } & $\underline{3}$ & 64.59 & 0.21 & 16.62 & 4.38 & 0.22 & 0.12 & 0.60 & 8.33 & 4.90 & 0.03 & 98.00 & f \\
\hline & & $\mathrm{SiO}_{2}$ & $\mathrm{TiO}_{2}$ & $\mathrm{Al}_{2} \mathrm{O}_{3}$ & $\mathrm{FeO}$ & MnO & $\mathrm{MgO}$ & $\mathrm{CaO}$ & $\mathrm{Na}_{2} \mathrm{O}$ & $\mathrm{K}_{2} \mathrm{O}$ & $\mathrm{P}_{2} \mathrm{O}_{5}$ & Total & Std file \\
\hline MFM T239 & 1 & 63.87 & 0.08 & 19.03 & 0.96 & 0.09 & 0.41 & 1.78 & \begin{tabular}{|l|}
6.39 \\
\end{tabular} & 7.38 & 0.01 & 100.36 & $a$ \\
\hline MFM T239 & 2 & 67.85 & 0.59 & \begin{tabular}{|l|l|}
14.73 \\
\end{tabular} & 4.68 & 0.17 & 1.88 & 0.25 & 2.80 & 6.86 & 0.18 & 99.85 & $\mathrm{a}$ \\
\hline
\end{tabular}

Table S2:

679 Summary of measured secondary standard glass ((ATHO-G and StHs6/80-G from the MPI-DING 680 collection, Jochum et al., 2006) compositions by (a) WDS-EPMA and (b) LA-ICP-MS. Preferred values 681 from the online GeoREM database are listed for comparison (Jochum et al., 2005).

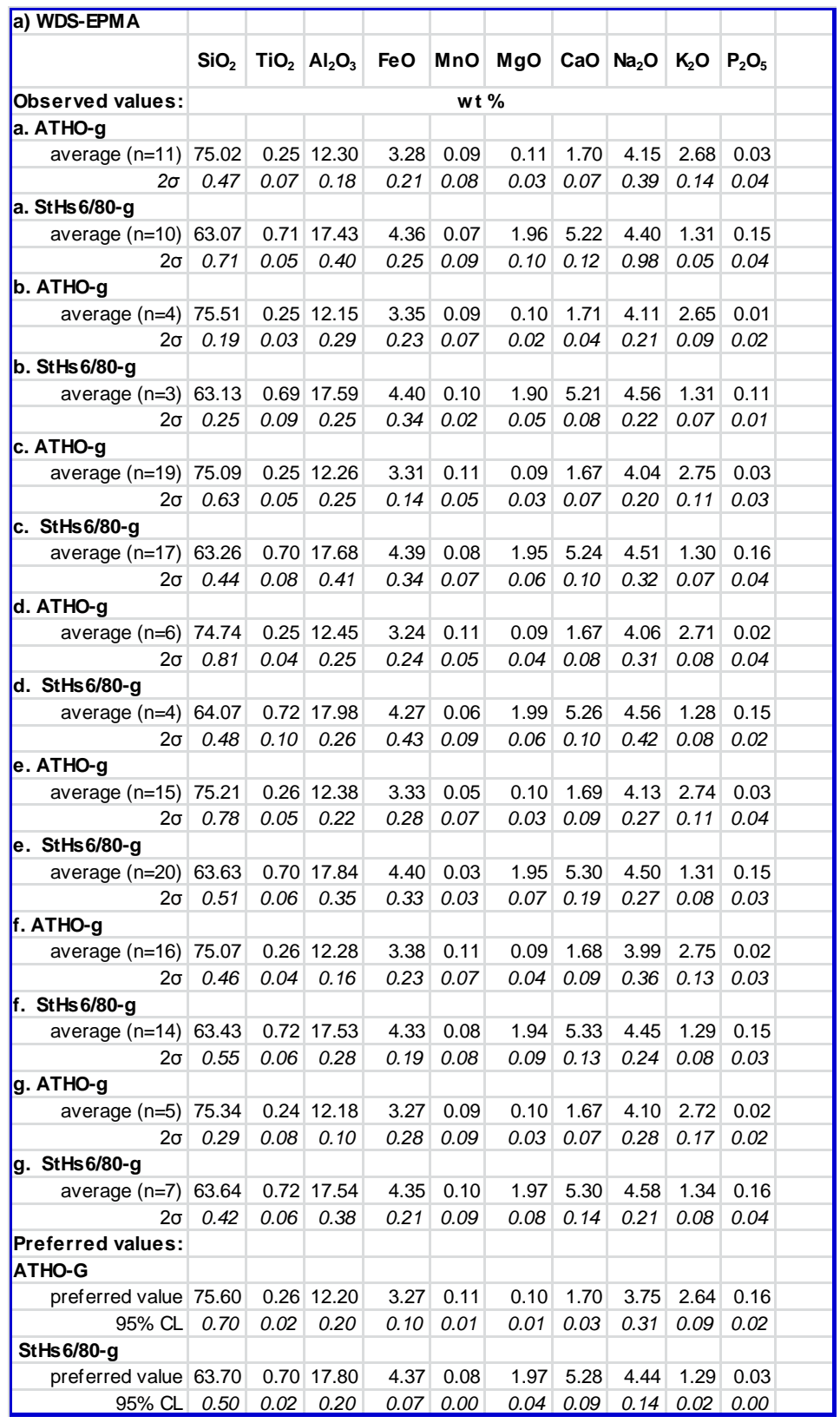




\begin{tabular}{|c|c|c|c|c|c|c|c|c|c|c|c|c|c|c|c|c|c|c|c|}
\hline \multirow[t]{3}{*}{ b) LA-ICP-MS } & & & & & & & & & & & & & & & & & & & \\
\hline & $\mathbf{R b}$ & $\mathrm{Sr}$ & $\mathbf{Y}$ & $\mathrm{Zr}$ & $\mathbf{N b}$ & $\mathrm{Ba}$ & La & $\mathrm{Ce}$ & $\mathrm{Pr}$ & Nd & Sm & Eu & Gd & Dy & Er & $\mathrm{Yb}$ & Ta & Th & U \\
\hline & \multicolumn{19}{|c|}{ (ppm) } \\
\hline \multicolumn{20}{|c|}{ Observed values: } \\
\hline \multicolumn{20}{|c|}{ a. ATHO-g } \\
\hline average $(n=3)$ & 67 & 98 & 94 & 511 & 59 & 567 & 56 & 125 & 15 & 62 & 15 & 2.6 & 14.7 & 16.8 & 10.3 & 10.7 & 3.8 & 7.4 & 2.4 \\
\hline $2 \sigma$ & 5.9 & 9.4 & 3.2 & 35.2 & 6.7 & 40.6 & 1.4 & 8.0 & 1.2 & 4.0 & 2.0 & 0.2 & 1.3 & 0.4 & 0.9 & 0.9 & 0.1 & 0.4 & 0.3 \\
\hline \multicolumn{20}{|l|}{ a. StHs 6/80-g } \\
\hline average $(n=3)$ & 30 & 489 & 11 & 117 & 6 & 300 & 12 & 25 & 3 & 13 & $<L O D$ & 1.0 & $<L O D$ & 2.2 & 1.2 & $<L O D$ & $<L O D$ & 2.3 & 1.0 \\
\hline $2 \sigma$ & 2.1 & 10.4 & 0.9 & 4.4 & 0.4 & 14.0 & 0.9 & 0.3 & 0.1 & 0.7 & $<$ LOD & 0.1 & $<L O D$ & 0.2 & 0.1 & $<L O D$ & $<L O D$ & 0.1 & 0.0 \\
\hline \multicolumn{20}{|l|}{ b. ATHO-g } \\
\hline average $(n=3)$ & 67 & 95 & 91 & 499 & 59 & 553 & 56 & 122 & 14 & 63 & 15 & 2.5 & 14.2 & 16.7 & 10.2 & 10.4 & 3.8 & 7.2 & 2.2 \\
\hline $2 \sigma$ & 1.8 & 8.0 & 7.0 & 35.6 & 2.1 & 26.0 & 4.2 & 8.4 & 0.6 & 9.8 & 2.3 & 0.2 & 1.3 & 1.8 & 0.7 & 1.3 & 0.2 & 1.0 & 0.2 \\
\hline \multicolumn{20}{|l|}{ b. StHs6/80-g } \\
\hline average $(n=3)$ & 31 & 480 & 11 & 115 & 6 & 297 & 12 & 25 & 3 & 12 & $<L O D$ & 0.9 & $<L O D$ & 2.2 & 1.4 & $<L O D$ & $<L O D$ & 2.2 & 1.4 \\
\hline $2 \sigma$ & 2.5 & 20.3 & 0.7 & 7.7 & 0.3 & 10.4 & 1.1 & 1.2 & 0.1 & 1.3 & $<L O D$ & 0.0 & $<L O D$ & 0.1 & 1.1 & $<L O D$ & $<L O D$ & 0.2 & 1.4 \\
\hline \multicolumn{20}{|l|}{ c. ATHO-g } \\
\hline average $(n=3)$ & 67 & 96 & 90 & 495 & 60 & 555 & 55 & 123 & 14 & 62 & 15 & 2.5 & 14.5 & 16.4 & 10.1 & 10.2 & 3.8 & 7.1 & 2.3 \\
\hline $2 \sigma$ & 7.7 & 6.5 & 5.9 & 39.0 & 5.3 & 29.7 & 2.4 & 7.8 & 0.9 & 2.9 & 1.9 & 0.2 & 0.5 & 0.9 & 0.6 & 0.7 & 0.3 & 0.3 & 0.1 \\
\hline \multicolumn{20}{|l|}{ c. StHs6/80-g } \\
\hline average $(n=3)$ & 30 & 471 & 11 & 112 & 7 & 294 & 11 & 25 & 3 & 13 & 3 & 0.9 & 3.1 & 2.2 & 1.3 & 1.3 & $<L O D$ & 2.2 & 0.9 \\
\hline $2 \sigma$ & 2.7 & 18.3 & 0.6 & 3.9 & 0.5 & 7.1 & 0.6 & 1.1 & 0.1 & 1.3 & 0.8 & 0.0 & 1.3 & 0.5 & 0.6 & 0.3 & $<L O D$ & 0.3 & 0.0 \\
\hline \multicolumn{20}{|l|}{ d. ATHO-g } \\
\hline average $(n=3)$ & 68.1 & 99.3 & 93.8 & 507.3 & 61.3 & 575.2 & 57.0 & 125.4 & 14.7 & 62.9 & 14 & 2.8 & 14.4 & 16.4 & 10.5 & 10.6 & 3.9 & 7.6 & 2.3 \\
\hline $2 \sigma$ & 3.0 & 2.0 & 3.0 & 20.5 & 1.6 & 6.4 & 1.3 & 2.5 & 0.5 & 1.2 & 2.1 & 0.1 & 0.3 & 0.6 & 0.6 & 0.5 & 0.1 & 0.3 & 0.1 \\
\hline \multicolumn{20}{|l|}{ d. StHs6/80-g } \\
\hline average $(n=3)$ & 31.8 & 485.0 & 11.0 & 115.5 & 6.6 & 301.0 & 11.9 & 25.6 & 3.0 & 12.8 & $<\mathrm{LOD}$ & 0.9 & 2.8 & 2.1 & 1.2 & 1.2 & 0.5 & 2.2 & 1.0 \\
\hline $2 \sigma$ & 1.0 & 10.8 & 0.4 & 2.8 & 0.5 & 2.5 & 0.3 & 0.8 & 0.2 & 1.3 & $<L O D$ & 0.0 & 0.6 & 0.2 & 0.1 & 0.1 & 0.0 & 0.2 & 0.0 \\
\hline \multicolumn{20}{|c|}{ Preferred values: } \\
\hline Atho-G & 65 & 94 & 95 & 512 & 62 & 547 & 56 & 121 & 15 & 61 & 14 & 2.8 & 15.3 & 16.2 & 10.3 & 10.5 & 3.9 & 7.4 & 2.4 \\
\hline StHs $6 / 80-G$ & 31 & 482 & 11.4 & 118.0 & 6.9 & 298.0 & 12.0 & 26.1 & 3.2 & 13.0 & 2.8 & 1.0 & 2.6 & 2.2 & 1.2 & 1.1 & 0.4 & 2.3 & 1.0 \\
\hline
\end{tabular}

\section{References}

686

687

Abbott, P.M., Davies, S.M., 2012. Volcanism and the Greenland ice-cores: The tephra record. extended intimate (integration of ice-core, marine and terrestrial records) event stratigraphy 8-128 ka b2k. Quaternary Science Reviews 106, 88-100. Turney, C.S.M., Molyneux, E.G., 2005. A new and less destructive laboratory procedure for the physical separation of distal glass tephra shards from sediments. Quaternary Science Reviews 24, 1952-1960. palaeoenvironmental records over the last 60,000 years, and an extended INTIMATE 1 event stratigraphy to 48,000 b2k. Quaternary Science Reviews 36, 2-10. 
Brauer, A., Endres, C., Zolitschka, B., Negendank, J.F.W., 2000a. AMS radiocarbon and varve chronology from the annually laminated sediment record of Lake Meerfelder Maar, Germany. Radiocarbon 42, 355-368.

Brauer, A., Günter, C., Johnsen, S.J., Negendank, J.F.W., 2000b. Land-ice teleconnections of cold climatic periods during the last Glacial/Interglacial transition. Climate Dynamics 16, 229-239.

Brauer, A., Allen, J.R.M., Mingram, J., Dulski, P., Wulf, S., Huntley, B., 2007. Evidence for last interglacial chronology and environmental change from Southern Europe. Proceedings of the National Academy of Sciences of the United States of America 104, 450-455.

Brauer, A., Haug, G.H., Dulski, P., Sigman, D.M., Negendank, J.F.W., 2008. An abrupt wind shift in western Europe at the onset of the Younger Dryas cold period. Nature Geoscience 1, 520-523.

Brauer, A., Hajdas, I., Blockley, S.P., Ramsey, C.B., Christl, M., Ivy-Ochs, S., Moseley, G.E., Nowaczyk, N.N., Rasmussen, S.O., Roberts, H.M., 2014. The importance of independent chronology in integrating records of past climate change for the 60-8 ka INTIMATE time interval. Quaternary Science Reviews 106, 47-66.

Bronk Ramsey, C., 2001. Development of the Radiocarbon Program OxCal. Radiocarbon 43, 355-364.

Bronk Ramsey, C., Albert, P.G., Blockley, S.P., Hardiman, M., Housley, R.A., Lane, C.S., Lee, S., Matthews, I.P., Smith, V.C., Lowe, J., in press-a. Improved age estimates for key Late Quaternary European tephra horizons in the RESET lattice. Quaternary Science Reviews.

Bronk Ramsey, C., Housley, R.A., Lane, C.S., Smith, V.C., Pollard, A.M., in press-b. The RESET tephra database and associated analytical tools. Quaternary Science Reviews.

Büchel, G., Lorenz, V., 1984. Zum Alter des Meerfelder Maares. G. Irion \& JFW Negendank, Cour. Forsch. Inst. Senckenberg 65, 13-15.

Chambers, F.M., Daniell, J.R.G., Hunt, J.B., Molloy, K., O'Connell, M., 2004. Tephrostratigraphy of An Loch Mór, Inis Oírr, western Ireland: Implications for Holocene tephrochronology in the northeastern Atlantic region. Holocene 14, 703-720.

Civetta, L., Cornette, Y., Crisci, P.Y., Orsi, G., Requejo, C.S., 1984. Geology, geochronology and chemical evolution of the island of Pantelleria. Geological Magazine 121, 541-562.

Davies, S.M., Abbott, P.M., Pearce, N.J.G., Wastegård, S., Blockley, S.P.E., 2012. Integrating the INTIMATE records using tephrochronology: Rising to the challenge. Quaternary Science Reviews 36, 11-27. 
Deino, A.L., Orsi, G., de Vita, S., Piochi, M., 2004. The age of the Neapolitan Yellow Tuff caldera-forming eruption (Campi Flegrei caldera - Italy) assessed by 40Ar/39Ar dating method. Journal of Volcanology and Geothermal Research 133, 157-170.

Dugmore, A.J., Larsen, G., Newton, A.J., 1995. Seven tephra isochrones in Scotland. Holocene 5, 257-266.

Gertisser, R., Self, S., Gaspar, J.L., Kelley, S.P., Pimentel, A., Eikenberg, J., Barry, T.L., Pacheco, J.M., Queiroz, G., Vespa, M., 2010. Ignimbrite stratigraphy and chronology on Terceira Island, Azores.

Hajdas, I., 1993. AMS radiocarbon dating and varve chronology of Lake Soppensee: 6000 to $1200014 C$ years BP. Climate Dynamics 9, 107-116.

Housley, R.A., Lane, C.S., Cullen, V.L., Weber, M.J., Riede, F., Gamble, C.S., Brock, F., 2012. Icelandic volcanic ash from the Late-glacial open-air archaeological site of Ahrenshöft LA 58 D, North Germany. Journal of Archaeological Science 39, 708-716.

Jochum, K.P., Nohl, U., Herwig, K., Lammel, E., Stoll, B., Hofmann, A.W., 2005. GeoReM: A new geochemical database for reference materials and isotopic standards. Geostandards and Geoanalytical Research 29, 333-338.

Jochum, K.P., Stoll, B., Herwig, K., Willbold, M., Hofmann, A.W., Amini, M., Aarburg, S., Abouchami, W., Hellebrand, E., Mocek, B., Raczek, I., Stracke, A., Alard, O., Bouman, C., Becker, S., Ducking, M., Bratz, H., Klemd, R., de Bruin, D., Canil, D., Cornell, D., de Hoog, C.J., Dalpe, C., Danyushevsky, L., Eisenhauer, A., Gao, Y.J., Snow, J.E., Goschopf, N., Gunther, D., Latkoczy, C., Guillong, M., Hauri, E.H., Hofer, H.E., Lahaye, Y., Horz, K., Jacob, D.E., Kassemann, S.A., Kent, A.J.R., Ludwig, T., Zack, T., Mason, P.R.D., Meixner, A., Rosner, M., Misawa, K.J., Nash, B.P., Pfander, J., Premo, W.R., Sun, W.D.D., Tiepolo, M., Vannucci, R., Vennemann, T., Wayne, D., Woodhead, J.D., 2006. MPI-DING reference glasses for in situ microanalysis: new reference values for element concentrations and isotope ratios. Geochemistry Geophysics Geosystems 7.

Johannesson, H.L., E. M.; Wastegård, S., in press. Proximal tephra glass geochemistry from eruptions in the Azores archipelago and links with distal sites in Ireland. The Holocene.

Koren, J.H., Svendsen, J.I., Mangerud, J., Furnes, H., 2008. The Dimna Ash - a $12.814 \mathrm{C}$ ka-old volcanic ash in Western Norway. Quaternary Science Reviews 27, 85-94.

Lacasse, C., Garbe-Schönberg, C.D., 2001. Explosive silicic volcanism in Iceland and the Jan Mayen area during the last 6Ma: sources and timing of major eruptions. Journal of Volcanology and Geothermal Research 107, 113-147.

Lane, C.S., Andrič, M., Cullen, V.L., Blockley, S.P.E., 2011a. The occurrence of distal Icelandic and Italian tephra in the Lateglacial of Lake Bled, Slovenia. Quaternary Science Reviews 30, 1013-1018. 
Lane, C.S., Blockley, S.P.E., Bronk Ramsey, C., Lotter, A.F., 2011b. Tephrochronology and absolute centennial scale synchronisation of European and Greenland records for the last glacial to interglacial transition: A case study of Soppensee and NGRIP. Quaternary International, 145-156.

Lane, C.S., Blockley, S.P.E., Lotter, A.F., Finsinger, W., Filippi, M.L., Matthews, I.P., 2012a. A regional tephrostratigraphic framework for central and southern European climate archives during the Last Glacial to Interglacial transition: Comparisons north and south of the Alps. Quaternary Science Reviews 36, 50-58.

Lane, C.S., Blockley, S.P.E., Mangerud, J., Smith, V.C., Lohne, $\varnothing$., Tomlinson, E.L., Matthews, I.P., Lotter, A.F., 2012b. Was the 12.1ka Icelandic Vedde Ash one of a kind? Quaternary Science Reviews 33, 87-99.

Lane, C.S., De Klerk, P., Cullen, V.L., 2012c. A tephrochronology for the Lateglacial palynological record of the Endinger Bruch (Vorpommern, north-east Germany). Journal of Quaternary Science 27, 141-149.

Lane, C.S., Brauer, A., Blockley, S.P.E., Dulski, P., 2013. Volcanic ash reveals timetransgressive abrupt climate change during the Younger Dryas. Geology 41, 1251-1254.

Lane, C.S., Cullen, V., White, D., Bramham-Law, C., Smith, V., 2014. Cryptotephra as a dating and correlation tool in archaeology. Journal of Archaeological Science 42, 42-50.

Le Bas, M.J., Le Maitre, R.W., Streckeisen, A., Zanettin, B., 1986. A chemical classification of volcanic rocks based on the total alkali-silica diagram. Journal of Petrology 27, 745-750.

Litt, T., Stebich, M., 1999. Bio- and chronostratigraphy of the lateglacial in the Eifel region, Germany. Quaternary International 61, 5-16.

Lohne, Ø.S., Mangerud, J.A.N., Birks, H.H., 2013. Precise $14 C$ ages of the Vedde and Saksunarvatn ashes and the Younger Dryas boundaries from western Norway and their comparison with the Greenland Ice Core (GICC05) chronology. Journal of Quaternary Science 28, 490-500.

Lowe, J.J., 2001. Abrupt climatic changes in Europe during the last glacial-interglacial transition: The potential for testing hypotheses on the synchroneity of climatic events using tephrochronology. Global and Planetary Change 30, 73-84.

Macdonald, R., 1974. Nomenclature and petrochemistry of the peralkaline oversaturated extrusive rocks. Bulletin Volcanologique 38, 498-516.

Magny, M., Vannière, B., Calo, C., Millet, L., Leroux, A., Peyron, O., Zanchetta, G., La Mantia, T., Tinner, W., 2011. Holocene hydrological changes in south-western Mediterranean as recorded by lake-level fluctuations at Lago Preola, a coastal lake in southern Sicily, Italy. Quaternary Science Reviews 30, 2459-2475. 
Mahood, G.A., Hildreth, W., 1986. Geology of the peralkaline volcano at Pantelleria, Strait of Sicily. Bulletin of Volcanology 48, 143-172.

Mangerud, J., Lie, S.E., Furnes, H., Kristiansen, I.L., Lømo, L., 1984. A Younger Dryas Ash Bed in western Norway, and its possible correlations with tephra in cores from the Norwegian Sea and the North Atlantic. Quaternary Research 21, 85-104.

Martin-Puertas, C., Brauer, A., Dulski, P., Brademann, B., 2012a. Testing climate-proxy stationarity throughout the Holocene: an example from the varved sediments of Lake Meerfelder Maar (Germany). Quaternary Science Reviews 58, 56-65.

Martin-Puertas, C., Matthes, K., Brauer, A., Muscheler, R., Hansen, F., Petrick, C., Aldahan, A., Possnert, G., van Geel, B., 2012b. Regional atmospheric circulation shifts induced by a grand solar minimum. Nature Geosci 5, 397-401.

Matthews, I.P., Birks, H.H., Bourne, A.J., Brooks, S.J., Lowe, J.J., Macleod, A., Pyne-O'Donnell, S.D.F., 2011. New age estimates and climatostratigraphic correlations for the borrobol and penifiler tephras: Evidence from Abernethy Forest, Scotland. Journal of Quaternary Science $26,247-252$.

Mortensen, A.K., Bigler, M., Grönvold, K., Steffensen, J.P., Johnsen, S.J., 2005. Volcanic ash layers from the last glacial termination in the NGRIP ice core. Journal of Quaternary Science 20, 209-219.

Muscheler, R., Kromer, B., Björck, S., Svensson, A., Friedrich, M., Kaiser, K., Southon, J., 2008. Tree rings and ice cores reveal $14 C$ calibration uncertainties during the Younger Dryas. Nature Geoscience 1, 263-267.

Plunkett, G., 2009. Land-use patterns and cultural change in the Middle to Late Bronze Age in Ireland: Inferences from pollen records. Vegetation History and Archaeobotany 18, 273295.

Rach, O., Brauer, A., Wilkes, H., Sachse, D., 2014. Delayed hydrological response to Greenland cooling at the onset of the Younger Dryas in western Europe. Nature Geoscience 7, 109-112.

Rasmussen, S.O., Andersen, K.K., Svensson, A.M., Steffensen, J.P., Vinther, B.M., Clausen, H.B., Siggaard-Andersen, M.L., Johnsen, S.J., Larsen, L.B., Dahl-Jensen, D., Bigler, M., Röthlisberger, R., Fischer, H., Goto-Azuma, K., Hansson, M.E., Ruth, U., 2006. A new Greenland ice core chronology for the last glacial termination. Journal of Geophysical Research D: Atmospheres 111, D06102.

Reilly, E., Mitchell, F.J., 2014. Establishing chronologies for woodland small hollow and mor humus deposits using tephrochronology and radiocarbon dating. The Holocene. 
Reimer, P.J., Bard, E., Bayliss, A., Beck, J.W., Blackwell, P.G., Ramsey, C.B., Buck, C.E., Cheng, H., Edwards, R.L., Friedrich, M., 2013. IntCal13 and Marine13 radiocarbon age calibration curves 0-50,000 years cal BP. Radiocarbon 55, 1869-1887.

Riede, F., Bazely, O., Newton, A.J., Lane, C.S., 2011. A Laacher See-eruption supplement to Tephrabase: Investigating distal tephra fallout dynamics. Quaternary International 246, 134144.

Schmidt, R., Van Den Bogaard, C., Merkt, J., Müller, J., 2002. A new Lateglacial chronostratigraphic tephra marker for the south-eastern Alps: The Neapolitan Yellow Tuff (NYT) in Längsee (Austria) in the context of a regional biostratigraphy and palaeoclimate. Quaternary International 88, 45-56.

Siani, G., Sulpizio, R., Paterne, M., Sbrana, A., 2004. Tephrostratigraphy study for the last $18,00014 \mathrm{C}$ years in a deep-sea sediment sequence for the South Adriatic. Quaternary Science Reviews 23, 2485-2500.

Smith, V.C., Isaia, R., Pearce, N.J.G., 2011. Tephrostratigraphy and glass compositions of post-15 kyr Campi Flegrei eruptions: Implications for eruption history and chronostratigraphic markers. Quaternary Science Reviews 30, 3638-3660.

Steffensen, J.P., Andersen, K.K., Bigler, M., Clausen, H.B., Dahl-Jensen, D., Fischer, H., GotoAzuma, K., Hansson, M., Johnsen, S.J., Jouzel, J., Masson-Delmotte, V., Popp, T., Rasmussen, S.O., Röthlisberger, R., Ruth, U., Stauffer, B., Siggaard-Andersen, M.L., Sveinbjörnsdóttir, Á.E., Svensson, A., White, J.W.C., 2008. High-resolution greenland ice core data show abrupt climate change happens in few years. Science 321, 680-684.

Tomlinson, E.L., Thordarson, T., Müller, W., Thirlwall, M., Menzies, M.A., 2010. Microanalysis of tephra by LA-ICP-MS - Strategies, advantages and limitations assessed using the Thorsmörk ignimbrite (Southern Iceland). Chemical Geology 279, 73-89.

Tomlinson, E.L., Arienzo, I., Civetta, L., Wulf, S., Smith, V.C., Hardiman, M., Lane, C.S., Carandente, A., Orsi, G., Rosi, M., Müller, W., Menzies, M.A., 2012. Geochemistry of the Phlegraean Fields (Italy) proximal sources for major Mediterranean tephras: Implications for the dispersal of Plinian and co-ignimbritic components of explosive eruptions. Geochimica et Cosmochimica Acta 93, 102-108.

Tomlinson, E.L., Smith, V.C., Albert, P.G., Aydar, E., Civetta, L., Cioni, R., Çubukçu, E., Gertisser, R., Isaia, R., Menzies, M.A., Orsi, G., Rosi, M., Zanchetta, G., in press. The major and trace element glass compositions of the productive Mediterranean volcanic sources: tools for correlating distal tephra layers in and around Europe. Quaternary Science Reviews.

Turney, C.S.M., 1998. Extraction of rhyolitic component of Vedde microtephra from minerogenic lake sediments. Journal of Paleolimnology 19, 199. 
877 van den Bogaard, P., Schmincke, H.U., 1985. Laacher See tephra: a widespread isochronous 878 late Quaternary tephra layer in central and northern Europe. Geological Society of America 879 Bulletin 96, 1554-1571.

880 van Geel, B., Engels, S., Martin-Puertas, C., Brauer, A., 2013. Ascospores of the parasitic 881 fungus Kretzschmaria deusta as rainstorm indicators during a late Holocene beech-forest 882 phase around lake Meerfelder Maar, Germany. Journal of Paleolimnology 50, 33-40.

883 Wastegård, S., 2002. Early to middle Holocene silicic tephra horizons from the Katla volcanic 884 system, Iceland: New results from the Faroe Islands. Journal of Quaternary Science 17, 723885730.

886 Wulf, S., Kraml, M., Brauer, A., Keller, J., Negendank, J.F.W., 2004. Tephrochronology of the 887 100ka lacustrine sediment record of Lago Grande di Monticchio (southern Italy). Quaternary 888 International 122, 7-30.

889 Wulf, S., Kraml, M., Keller, J., 2008. Towards a detailed distal tephrostratigraphy in the 890 Central Mediterranean: The last 20,000 yrs record of Lago Grande di Monticchio. Journal of 891 Volcanology and Geothermal Research 177, 118-132.

892 Wulf, S., Keller, J., Paterne, M., Mingram, J., Lauterbach, S., Opitz, S., Sottili, G., Giaccio, B., 893 Albert, P.G., Satow, C., Tomlinson, E.L., Viccaro, M., Brauer, A., 2012. The 100-133 ka record 894 of Italian explosive volcanism and revised tephrochronology of Lago Grande di Monticchio. 895 Quaternary Science Reviews 58, 104-123.

896 Wulf, S., Ott, F., Słowiński, M., Noryśkiewicz, A.M., Dräger, N., Martin-Puertas, C., Czymzik, 897 M., Neugebauer, I., Dulski, P., Bourne, A.J., Błaszkiewicz, M., Brauer, A., 2013. Tracing the 898 Laacher See Tephra in the varved sediment record of the Trzechowskie palaeolake in central 899 Northern Poland. Quaternary Science Reviews 76, 129-139.

900 Zolitschka, B., Negendank, J.F.W., Lottermoser, B.G., 1995. Sedimentological proof and 901 dating of the Early Holocene volcanic eruption of Ulmener Maar (Vulkaneifel, Germany). 902 Geologische Rundschau 84, 213-219.

903 Zöller, L., Blanchard, H., 2009. The partial heat-longest plateau technique: Testing TL dating 904 of Middle and Upper Quaternary volcanic eruptions in the Eifel Area, Germany. E\&G 905 Quaternary Science Journal 58, 86-106. 